\title{
Feasibility study of installation of MW level grid connected solar photovoltaic power plant for northeastern region of India
}

\author{
PANKAJ KALITA $^{1, *}$, SAMAR DAS $^{1}$, DUDUL DAS $^{1}$, PALLAB BORGOHAIN $^{2}$, \\ ANUPAM DEWAN $^{3, *}$ and RABINDRA KANGSHA BANIK ${ }^{1}$ \\ ${ }^{1}$ Centre for Energy, Indian Institute of Technology Guwahati, Guwahati 781039, India \\ ${ }^{2}$ Department of Electrical Engineering, National Institute of Technology Silchar, Silchar 788010, India \\ ${ }^{3}$ Department of Applied Mechanics, Indian Institute of Technology Delhi, Hauz Khas, New Delhi 110016 , \\ India \\ e-mail: pankajk@iitg.ac.in; dsamar@iitg.ac.in; dudul.das@iitg.ac.in; pallabborg123@gmail.com; \\ adewan@am.iitd.ac.in; rabindra@iitg.ac.in
}

MS received 13 February 2019; revised 1 August 2019; accepted 7 August 2019

\begin{abstract}
Solar energy is one of the most suitable renewable energy options in India. In the last decade, solar energy installations have received an ample impetus in India due to active initiatives taken by the Indian government. However, the solar energy potential of country's North-Eastern (NE) part is not utilized effectively so far. In the present study, a comprehensive analysis of the feasibility of installation of a megawatt-level gridconnected solar photovoltaic (SPV) power plant in all the state capitals of NE India is carried out. The climatic data collected from various online sources and NASA climatic database were utilized in designing a 2 MW SPV plant. The theoretical procedure involved in designing the SPV plant is also presented in this study. PVsyst simulation software is used to predict the performance of $2 \mathrm{MW}$ power plants for these eight states of India. From the analysis, it is observed that NE India has an immense potential for installation of solar energy conversion devices and thus it can be harvested economically. It has been observed that locations of Guwahati and Gangtok provide a high performance ratio of 0.855 . Aizawl provides the minimum unit cost of electricity generated at a value of 3.88 INR/unit. The analysis also reveals that the Aizawl and Guwahati are the most suitable locations for installation of SPV power plant amongst the NE capitals.
\end{abstract}

Keywords. North-east India; PV power plant; PVsyst simulation; life cycle assessment; economic analysis; $\mathrm{CO}_{2}$ mitigation.

\section{Introduction}

Energy is the basic need of all living beings on the planet. The Sun is directly or indirectly responsible for all energy sources available on earth. A secure and sufficient supply of energy is very crucial for the sustainability of modern societies. With the passage of time, the world has eagleeyed several developments, such as, changes in the ongoing trends of the energy scenario and renewable energy technologies increasing its hold on the energy scenario. Energy security concept emerged in the early 20th century in connection with world wars, when a majority of the military fuel demand was met through fossil fuels [1]. Energy security is now closely entangled with other policy issues, such as, mitigating climate change and assurance to equitable access to modern energy [2,3]. According to Baldwin, security is a "low probability of damage to

*For correspondence

Published online: 05 September 2019 acquired values". When it comes to energy security, the "4A theory" always comes into context. The four A's of energy security are Availability, Affordability, Accessibility, and Acceptability. Two A's - availability and affordability are prominent in defining energy security. These two A's are also the heart and soul of energy security definition provided by International Energy Agency which defines energy security "as the uninterrupted availability of energy sources at an affordable price" [4]. At present approximately $70 \%$ of India's energy requirement is fulfilled by fossil fuel based thermal power plants [5]. It is due to a large scale emission from these fossil fuel based power plants, India is ranked fourth by World Resources Institute; India accounts for $6.65 \%$ of global emission in the regionwise carbon dioxide emission of the world [6]. As one of the signatories of Paris Summit on Climate Change, India is obliged to reduce its emission levels. In most of the countries, the coal demand decreased sharply after 2015, which is an outcome of Paris Climate Summit and growing 
awareness of the world community against global warming and climate change [2].

India is one of the top coal consumers, its consumption in 2015 was $10 \%$ of the world's coal demand which is expected to get doubled by 2035 [7]. Thus for India, it is a difficult choice to be made between fossil fuels and other sources of energy. The Gulf crisis of 2008 appropriately proved the importance of renewable sources of energy as it compelled the oil opulent countries of Middle East Asia to opt for renewables [8]. For India to maintain a steady economic growth, it has to increase the electricity supply, but the sources of electricity need to be eco-friendly as a mandate to its commitment towards reducing greenhouse gas emissions. Renewable energy is one of the suitable options which can relieve India from this dilemma, especially solar energy. India lies in the sunny belt of the northern hemisphere between the Tropics of Cancer and the Equator and most parts of India get sunshine for most of the year. Thus, India has a huge potential for solar energy utilization. Solar energy in India easily qualifies for the Four A theory and it is expected that solar resources and PV technology are likely to play a key role in decarbonizing India's electricity sector [9].

Post-independence, Government of India has implemented a wide range of policies by creating an efficient regulatory mechanism to support the growth of solar energy. In order to explore its huge potential of solar energy, the central government has set a target of achieving $100 \mathrm{GW}$ of solar power till 2022 under Jawaharlal Nehru National Solar Mission (JNNSM) [10]. Up to March 2016, the total cumulative installed capacity of the utility-scale solar power projects in India is $8118 \mathrm{MW}$ only [11]. But, during 2014-16, a capacity addition of $14.30 \mathrm{GW}$ of renewable energy has been reported under Grid Connected Renewable Power, of which $5.8 \mathrm{GW}$ is from solar power [12]. Execution of Feed-in Tariff for solar energy has already gained recognition in India [13]. Though Government of India has made constant efforts to improve the energy accessibility of its citizens, still the per capita energy consumption (1075 kWh/year) stands low as against the world average $(3126 \mathrm{kWh} /$ year $)$. Furthermore, 580 million people lack access to electricity in India [7]. Figure 1 shows the difference of the per capita energy consumption in India with respect to some of the other countries in the world.

Although the dominance of thermal power in India's present energy scenario is a major concern, rise in the installation of renewable energy sources is a silver lining for future of India's energy security. As discussed earlier, due to an abundant availability of sunshine throughout the country and maturity of solar energy conversion technologies, solar energy has become quite popular in India. It has the highest share (62\%) in the installed renewable energy capacity sector, followed by wind (34\%) whose availability is facilitated by India's $7500 \mathrm{~km}$ coastline having sufficient wind speed for running the wind turbines (figure 2).

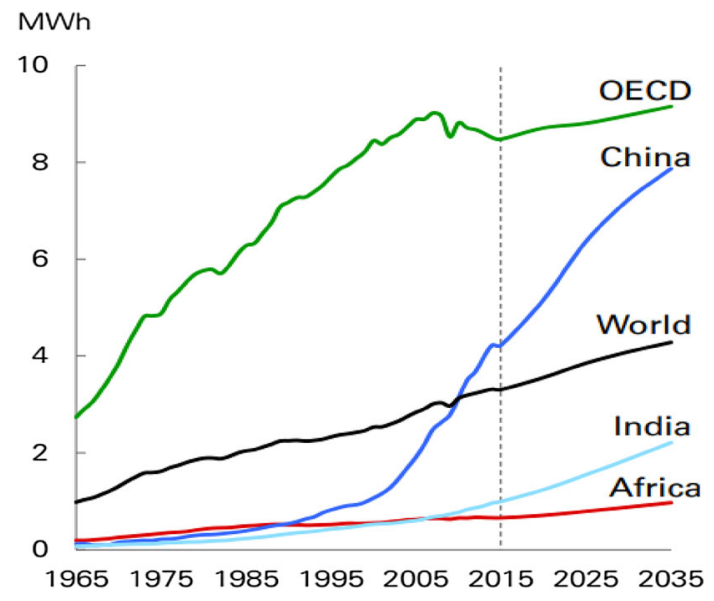

Figure 1. Per capita energy consumption of different countries [7].

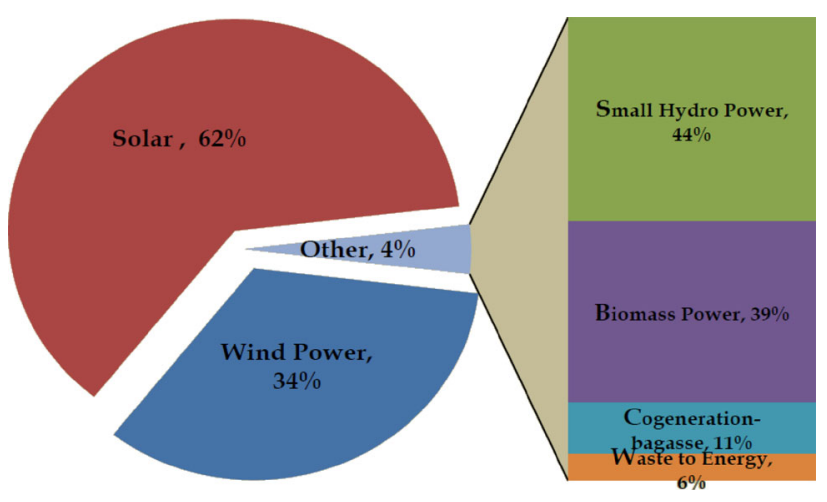

Figure 2. Renewable power in India [14].

Despite such a commendable development in the country's energy sector, its NE region is yet to feel the energy revolution which the rest of the country is experiencing. Figure 3 shows region-wise installed generation capacity of electricity in India, of which NE region shares only $1 \%$. NE India starves from power in spite of its huge energy potential. It is ranked low in terms of both the power generation and consumption. In terms of per capita energy consumption, the average per capita energy consumption for the NE region is approximately 300 units per person per year, whereas the national average is approximately 914 units per person per year. The average access to electricity in villages of NE India is not appreciable, only $53 \%$ of the rural population in the region has access to electricity. Access to electricity in the case of Assam is the worst (37\%) and Mizoram ranks the highest (84\%) [14]. This poor electrification is also brought up by factors, such as, improper infrastructure and connectivity, inhospitable weather conditions, etc. The NE region of the country has a total installed capacity of $3,550.02$ megawatts (MW) for electricity generation. Gas, coal and diesel based power plants together contribute to $57.6 \%$ of the 


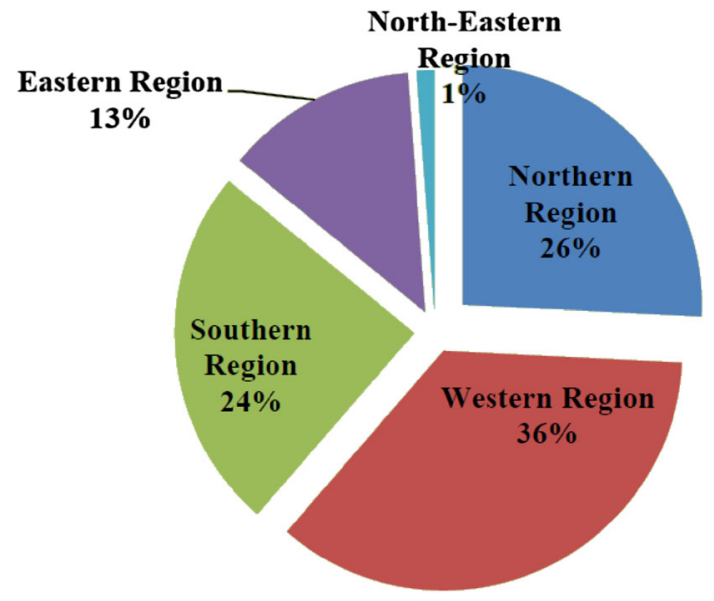

Figure 3. Region-wise installed generation capacity of electricity (utilities) [15].

installed capacity. Share of the renewable as can be seen from figure 4 is $7.43 \%$, of this again solar energy constitutes the major part. The government has tried its best in deploying solar energy technologies in NE India to improve the energy accessibility of the region. During 2016-2017, the Ministry of New and Renewable Energy (MNRE) sanctioned 16 numbers of solar PV power plants with an aggregate capacity of $440 \mathrm{~kW}_{\mathrm{p}}$ and 400 Solar Street Lights (LED) at various locations in the state of Assam, distributed 4000 solar lanterns in the villages of Mizoram and distributed 7078 solar home lighting systems for the Handloom Weavers of Manipur [15].

Energy generation from solar energy is the most underutilized source of renewable energy in the NE region of India. The region has a combined potential for installation of $62 \mathrm{GW}$ of solar power, but the installed capacity is approximately $50 \mathrm{MW}$ which is significantly lower compared to the available potential [16]. Table 1 shows the potential of solar energy and installation capacity of solar PV in NE India. It is observed that less than $1 \%$ of the solar potential in NE India has been utilized so far (table 1). Harnessing solar power is dependent on number of factors, such as, irradiation of the location, amount of daylight hours and meteorological conditions, such as, wind speed, temperature, rainfall or precipitation, humidity, cloudiness, etc. The NE region of India lies in the proximity of the Tropic of Cancer and thus characterizes tropical climate to a larger extent, especially in the valleys, even though there is a climatic contrast between the valleys and mountainous regions [17]. The possibility of installing large scale solar energy systems can be observed from the climatic study of $\mathrm{NE}$ India, however, thorough technical and economic assessment is necessary. Sufficient focus should also be put on power system flexibility for retaining supply-demand balance within the industry standards [18]. The economic assessment before installing a large scale renewable energy plant should also incorporate a regional impact assessment

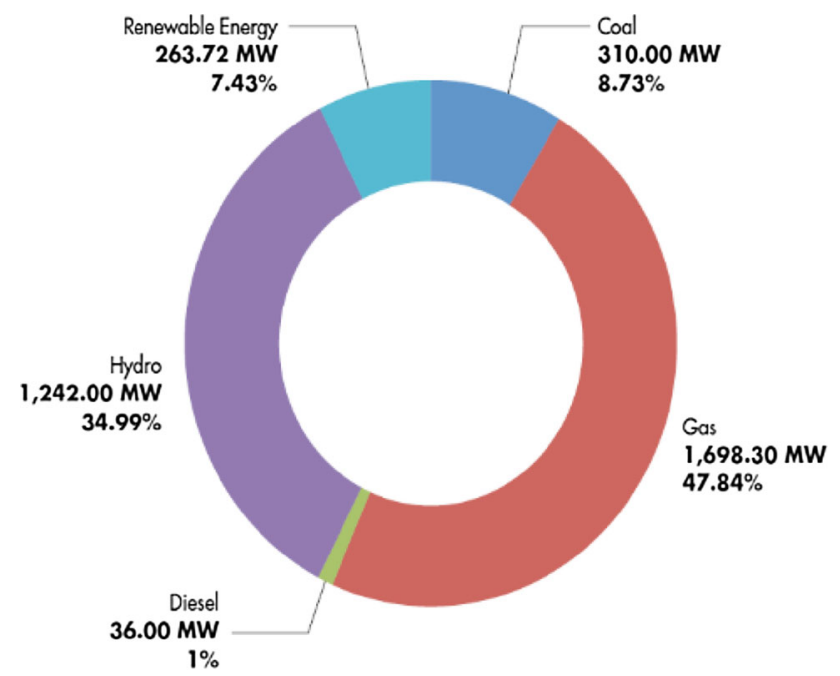

Figure 4. Sources of electricity in North-eastern India [14].

Table 1. State-wise solar energy potential and installed capacity [15].

\begin{tabular}{lcc}
\hline State & Potential in MW & Installed capacity in MW \\
\hline Arunachal Pradesh & 9000 & 0.27 \\
Assam & 14000 & 11.18 \\
Manipur & 11000 & 0.01 \\
Meghalaya & 6000 & 0.01 \\
Mizoram & 9000 & 0.1 \\
Nagaland & 7000 & 0.5 \\
Sikkim & 5000 & 0.01 \\
Tripura & 2000 & 17.1 \\
\hline
\end{tabular}

with emphasis on employment generation, socio-economic impact and its environmental benefits [19]. Most of the land in NE region is either owned, controlled or managed by tribes, clans or village communities. A PV power plant installation requires a large tract of land and its acquisition is a difficult task for the installing party due to both legal and political reasons. The land to be used for the installation should not be an agricultural land or a densely covered forest. There are barren lands available and a floating PV plant can be a viable option in the region, as the NE region is abundant with natural water bodies, such as, Deepor Beel, Loktak lake, Umian lake, etc. A PV plant has benefits of being eco-friendly and reliable. It can create jobs for the local communities and lower down the cost of power. The local communities need to be sensitised with the benefits of a PV power plant. A holistic approach involving the public, government, academia, media and international organizations need to be adopted to ensure social acceptance of solar power generation. In the recent years, Government of India has taken significant initiatives for utilizing solar 
potential in the NE states. In order to design grid connected SPV power plant for a particular location, a thorough analysis is of paramount importance by considering various geographical and climatic parameters. The studies on gridconnected PV systems have been carried out by a host of researchers across the globe. A report of selected research work on grid-connected solar PV power systems is presented in table 2.

From the above-mentioned literature survey, it is evident that several authors have performed various experiments and proposed numerous designs for generation of electricity using solar photovoltaic technology across India but negligible studies have been reported on exploring the solar energy potential of the North-eastern part of India. In the present investigation, the climatic data collected from various online sources and NASA climatic database, for the eight state capitals of NE India were compared and utilized in designing a $2 \mathrm{MW}$ SPV plant. The theoretical procedure involved in designing the SPV plant is also discussed in this study. PVsyst simulation software is used to predict the performance of the $2 \mathrm{MW}$ power plant for these eight states of India and results are compared based on the performance ratio, cost of energy, carbon dioxide mitigation, etc. Additionally, to justify the feasibility of a large-scale SPV plant, the results are also compared with three major cities of the country based on the contrasting climatic conditions.

\section{Design methodology of PV power plant}

Design of a solar PV power plant involves a systematic approach which enables a designer to achieve a high performance both technically and economically. The accomplishment of a solar PV system mostly concerns the amount of energy yield and active operational time, which relies on the operational conditions and the detailed arrangement of the system. On the other hand, location of the system defines the operating conditions, i.e., availability of solar radiation, ambient temperature and several climatic aspects which directly influence the system performance [35]. Some other factors, such as, quality and reliability of the components used, expertise and diligence during installation, operation and maintenance of the system are also responsible for performance, reliability, life and safety of the plant [36]. Complexity associated with large-scale grid connected power plant design can be resolved with a significant technical experience and knowledge by maintaining an optimum balance between energy performance and cost [37]. According to Rawat et al [38] complication associated with the power electronic devices, i.e., inverters and transformers due to minimization of harmonic distortion, matching frequency and voltage with the utility grid increases the complexity of grid connected PV systems. Anzalchi et al [39] mentioned about technical improvements in system design, better power electronics, standardization and simplified procedures of grid integration which are different ways for achieving good economics of PV systems. Berwal et al [40] have reported a $50 \mathrm{~kW}$ solar PV system design, PV array and inverter sizing along with selection criteria of PV system. The author also discussed about the stages, i.e., conceptual, pre-feasibility analysis, feasibility analysis, development and design associated with PV project development. Wu et al [41] presented a comparative review on guidelines and standards for grid integrated PV generation systems and, operation of PV system. The author also discussed the scope of improvement for the existing standards of interconnected PV systems. Photovoltaic site selection using multi-criteria decisionmaking techniques and geographical information system was presented by Hassan et al [42]. The authors also discussed uncertainties associated with site selection. Sidi et al [43] reported that monitoring of a PV plant power generation during its operation is important for proper performance evaluation of the system. Senol et al [44] presented a mechanism for a large PV plant design with an intention to provide standard guidelines to designer while selecting and installing a large PV system. They also reported that the design involves site survey, determination of mounting system, selection of PV technology and specifications related to PV module and inverters, assessing the factors, such as, electricity consumption and PV energy generation characteristics and considering the costs involved in the design process. Rawat et al [38] proposed a methodology to design grid connected PV system that aimed to achieve the most suitable PV system design both technically and economically. Detailed guidelines for the installation of a large PV power plant was also presented by Babatunde et al [45]. This section discusses the methodology that has been proposed for the design of the solar grid connected power plant. Figure 5 shows the individual design steps which are required to be followed under different stages of a PV power plant design.

The present study reports a detailed analysis of climatic conditions of different NE states of India (Assam, Arunachal Pradesh, Meghalaya, Mizoram, Nagaland, Manipur, Tripura and Sikkim) and hence can be used for proposing PV system designs in these states. The location of NE states is shown in figure 6. Two different design approaches are included in the work, viz., theoretical calculation and simulation. The climatic data is collected from various reliable sources and analyzed. Once the data is being analyzed, proper selection of PV power plant components is carried out in order to optimize the output and cost. The selection of appropriate components followed in the design of the system is based on the ratings of the components and cost of the components. The design procedure is discussed in details in the subsequent sections. 
Table 2. Review of work done on grid connected solar PV power systems.

\begin{tabular}{|c|c|c|}
\hline Author(s) (year) & Region of study & Thrust of the study \\
\hline $\begin{array}{l}\text { Akella et al (2009) } \\
\text { [20] }\end{array}$ & $\begin{array}{l}\text { Jaunpur, } \\
\text { Uttarakhand, } \\
\text { India }\end{array}$ & $\begin{array}{l}\text { Economic, social and environmental impact of } \\
\text { renewable energy systems }\end{array}$ \\
\hline $\begin{array}{l}\text { Muneer et al } \\
\quad(2005)[21]\end{array}$ & India & $\begin{array}{l}\text { Explored renewable energy potential of India to } \\
\text { fulfill the energy demand in } 2025\end{array}$ \\
\hline $\begin{array}{l}\text { Eltawil and Zhao } \\
\text { (2010) [22] }\end{array}$ & - & $\begin{array}{c}\text { Investigated the importance of a grid-connected } \\
\text { PV system and its associated technical and } \\
\text { potential problems }\end{array}$ \\
\hline $\begin{array}{l}\text { Mitavachan et al } \\
\text { (2011) [23] }\end{array}$ & $\begin{array}{l}\text { Kolar, } \\
\text { Karnataka, } \\
\text { India }\end{array}$ & $\begin{array}{l}\text { Performance study of a } 3 \text { MW grid-connected } \\
\text { solar photovoltaic power plant for the year } \\
2010\end{array}$ \\
\hline $\begin{array}{l}\text { Kornelakis and } \\
\text { Koutroulis } \\
(2009)[24]\end{array}$ & Greece & $\begin{array}{c}\text { Detailed analysis and methodology for design, } \\
\text { optimization and economic analysis of grid- } \\
\text { connected photovoltaic systems }\end{array}$ \\
\hline
\end{tabular}

Chandel et al (2014) [25]

Sukumaran and Sudhakar (2017) [26]

Alam Hossain
Mondal and
Sadrul Islam
(2011) [27]
Sukumaran and
Sudhakar
(2017) [28]
Moharil and
Kulkarni (2009)
[29]
Ayompe et al
(2011) [30]

Velasco et al (2011) [31]

Ramoliya (2015) [32]
Bangladesh

Cochin, India

Sagardeep Island, West

Bengal, India Dublin, Ireland

Sitapura, Jaipur, Technical and economic viability of a $2.5 \mathrm{MW}$ solar PV power plant

Performance evaluation of 2 MW SPV plant using PV simulation tool, SISIFO

Study of the grid-connected solar PV potential in Bangladesh using NASA SSE solar radiation data, HOMER (optimization software) and GeoSpatial toolkit

Performance study of 12 MW SPV plant using operation data and using simulation software i.e. PVsyst and SolarGis

Performance study of $25 \mathrm{~kW}_{\mathrm{p}}$ SPV plant

Evaluated the performance of a grid-connected photovoltaic system of $1.72 \mathrm{~kW}_{\mathrm{p}}$ capacity and compared the monitored data with results obtained from different systems located in different location, viz., Germany, Poland, Italy, Spain and Northern Ireland

MATLAB simulation technique for computing optimum sizing factor of a PV grid-connected system considering ideal working conditions Performance evaluation of a grid connected solar PV system using PVsyst
Important findings

Pointed great social benefits, such as, selfreliance, technological advances, jobs opportunities, etc.

Identified solar hydrogen mixed energy as the solution for future energy demand for the major cities in India

Over-sizing of PV generator in relation with the inverter can affect operational lifetime of the inverter.

Operating inverter in unity power factor minimizes islanding problem

Module temperature plays a more sensitive role than solar insolation in case of module efficiency

Suggested cooling mechanism to maintain the module operating temperature

Proposed a generalized procedure to determine optimal sizing of power plant, modules-

inverter matching, optimal installation of PV modules in available area, PV modules tilt angle and space between rows to avoid shadow loss

Developed a genetics algorithm based optimization process, to maximize the net economic profit generated during a system's lifetime

Estimated the land area requirement for the power plant which is about 13.11 acres that will generate $10.03 \mathrm{GWh}$ electricity in the initial year with $35.23 \%$ plant capacity factor

The plant covers area of 10 acres with a per year generation capacity of 2733.122 MWh with a performance ratio of $85.54 \%$.

Mitigation of 59,200 tonnes of $\mathrm{CO}_{2}$ emissions is reported

Bangladesh has different suitable locations for solar PV power plant installation

Reported that annual average performance ratio (PR) was $86.58 \%$

Reported improvement of social life of local population

Reported that higher wind speed and low ambient temperature of the monitored location favours the positive results even though with low insolation level

Under-sizing the inverter rating with respect to PV generator rating may result in a lower energy production

Calculated the performance ratio and various losses to evaluate the system and discussed the feasibility of installing a 1 MW solar PV plant 
Table 2 continued

\begin{tabular}{|c|c|c|c|}
\hline Author(s) (year) & Region of study & Thrust of the study & Important findings \\
\hline $\begin{array}{l}\text { Ramli et al (2015) } \\
\text { [33] }\end{array}$ & $\begin{array}{c}\text { Makkah, Saudi } \\
\text { Arabia }\end{array}$ & $\begin{array}{c}\text { Investigation of PV/inverter sizing using } \\
\text { HOMER }\end{array}$ & $\begin{array}{l}\text { Excess electricity, renewable electricity } \\
\text { fraction, net present cost and } \mathrm{CO}_{2} \\
\text { emissions percentage were calculated }\end{array}$ \\
\hline $\begin{array}{l}\text { Mondol et al } \\
\quad(2006)[34]\end{array}$ & - & $\begin{array}{l}\text { Sizing analysis of PV/inverter of solar grid- } \\
\text { connected PV system with the help of } \\
\text { TRNSYS simulation tool considering three } \\
\text { different parameters, such as, annual inverter } \\
\text { output per rated PV output, specific cost of } \\
\text { the system and annualised specific cost of the } \\
\text { system respectively }\end{array}$ & $\begin{array}{c}\text { The authors stated that the sizing depends on } \\
\text { PV/inverter cost ratio and suggested a } \\
\text { system with high inverter efficiency so that } \\
\text { to make PV/inverter sizing more flexible } \\
\text { without affecting the Performance ratio of } \\
\text { the system }\end{array}$ \\
\hline
\end{tabular}

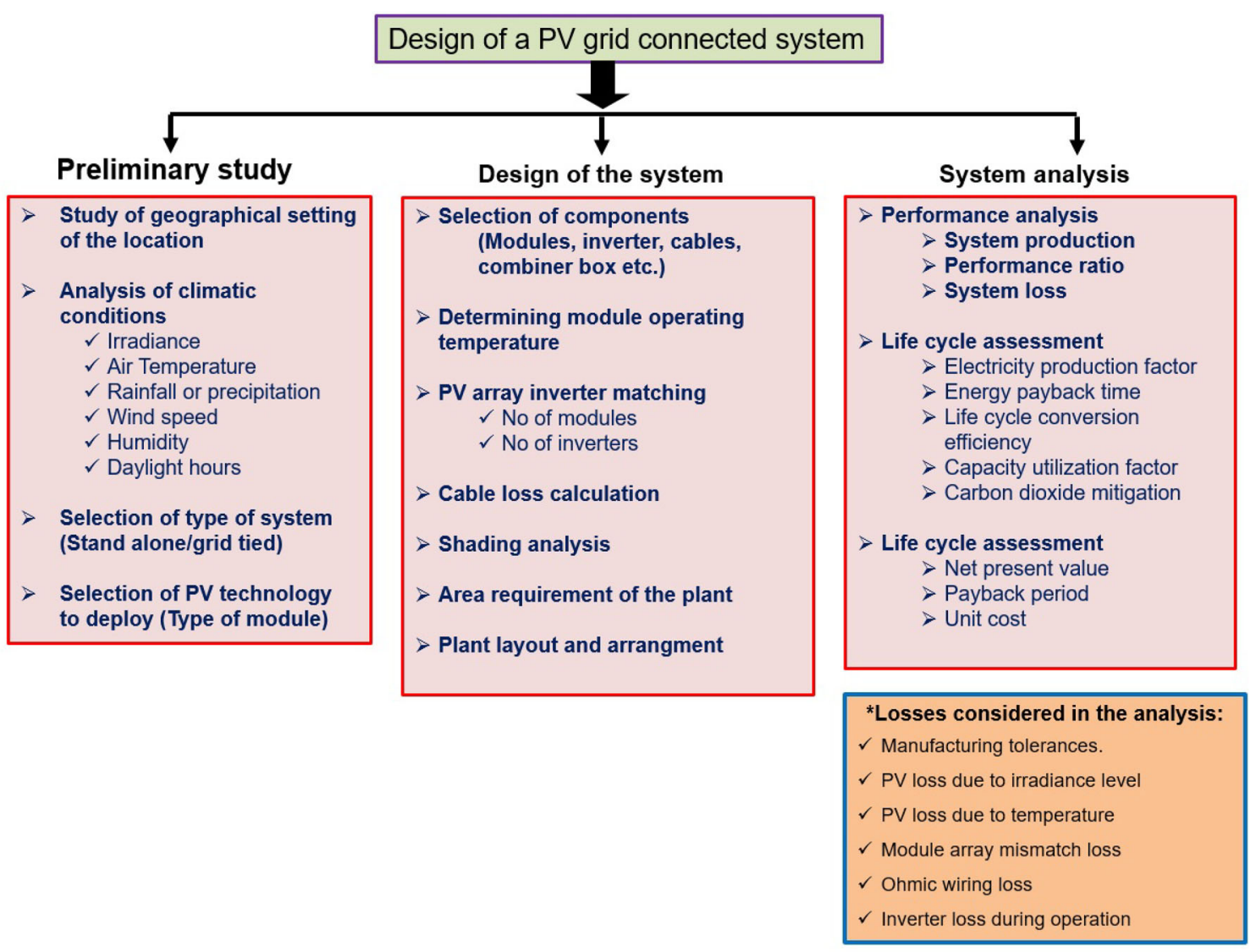

Figure 5. Design stages of the SPV power plant.

\subsection{Climatic conditions of Northeast India}

The annual power output of a PV power plant depends on various climatic conditions of the implementation site. The main factor on which the power output of a PV module depends is the irradiation that reaches module surface [47]. Other climatic parameters that affect the performance are temperature, dust and wind. The power output of the PV module decreases with an increase in the module temperature [48]. On the other hand, high speed wind results in a reduction of the PV cell temperature which subsequently enhances the overall performance of the module [49]. In desert areas, accumulation of dust on PV modules occurs naturally and it also affects the PV power output by reducing the module glass transmittance [50]. Cleaning of the modules as a part of preventive maintenance may significantly reduce the effect of dust [51]. Ndiaye et al [52] presented a review on temperature, humidity and UV radiation which are essentially responsible for a gradual degradation of PV module output after a period of operation. Similarly, Al-Sabounchi et al [53] also reported that the performance of PV Distributing Generation (PVDG) 


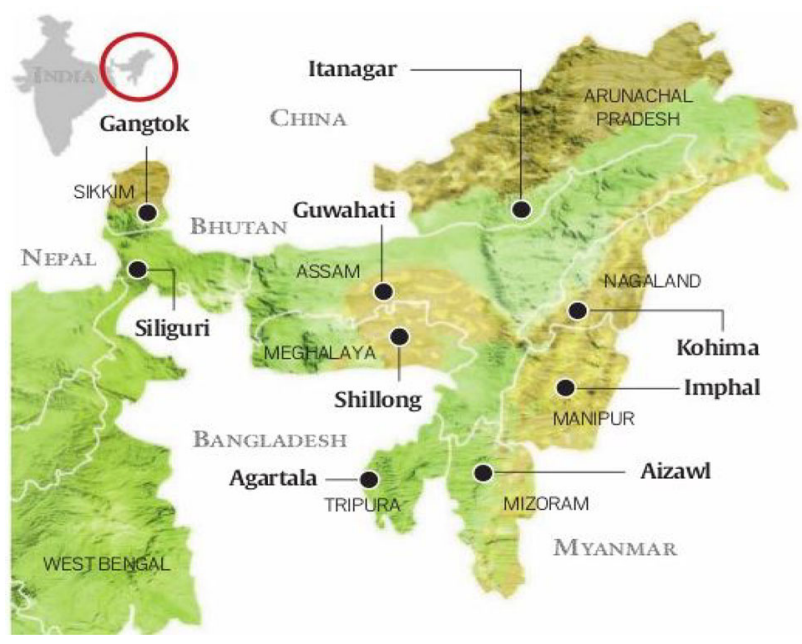

Figure 6. Map of NE India [46].

systems is vastly influenced by solar irradiance, ambient temperature and the other climatic parameters of the site and also reported that performance of an installed PV system is site specific.

From the above-mentioned studies, it is obvious that a proper information about different climatic conditions of the installation site is necessary beforehand installing a PV system. A systematic literature survey has been performed on the climatic conditions of NE region of India and studies dealing with solar energy installation and it is observed that very few studies have been reported. Jain et al [54] studied the trend of rainfall and temperature in NE region of India and concluded that there was large variability in magnitude and direction of rainfall in these regions having a rising trend in temperature. Bhattacharya et al [55] established a positive linear relationship between the module efficiency, ambient temperature and wind speed after studying their effects on the performance of a mono-crystalline SPV module in the state of Tripura, India. It is reported from the literature that the power output is inversely proportional to the ambient temperature [56]. Humidity and dust deposition also causes degradation in efficiency by affecting the solar irradiance (reflection, refraction or diffraction) and by entering into the solar cell enclosure [57]. An increase in the wind velocity removes heat from the solar cell surface by convection [58]. Higher wind velocity also lowers the relative humidity and increases electrical conversion efficiency. But, wind may also result in dust scattering which may negatively affect the electrical conversion efficiency [55]. The annual DNI map for North-East India is shown in figure 7 which has been prepared based on the data collected from National Institute of Wind Energy website.

In this section, a detailed climatic study is carried out for the eight capitals of NE states. It is observed from figure 8 that the Direct Normal Radiation (DNI) is comparatively lower during the months of June-September. This behavior is because during this time monsoon season prevails in NE with a heavy rainfall, thus reducing the DNI for this period. The curve dips highest for Shillong in the month of JuneSeptember. Because, during this period Shillong receives the maximum rainfall owing to its topography, i.e., Meghalaya hills form the first orographic barrier for the humid southwest monsoon winds, on their way from the Bay of Bengal to the Himalayas and approximately $80 \%$ of the annual rainfall occurs between June and September [59]. However, DNI value suffers lowest fluctuation for the city of Gangtok due to the precipitation pattern of the place as given in table 3 . For all the places, the graph initially has a higher value in the months of January-March and then it starts showing a decreasing trend after which the normal radiation increases again slowly and attains higher values in the months of November-December. The direct normal radiation values for Guwahati are a bit higher in the months

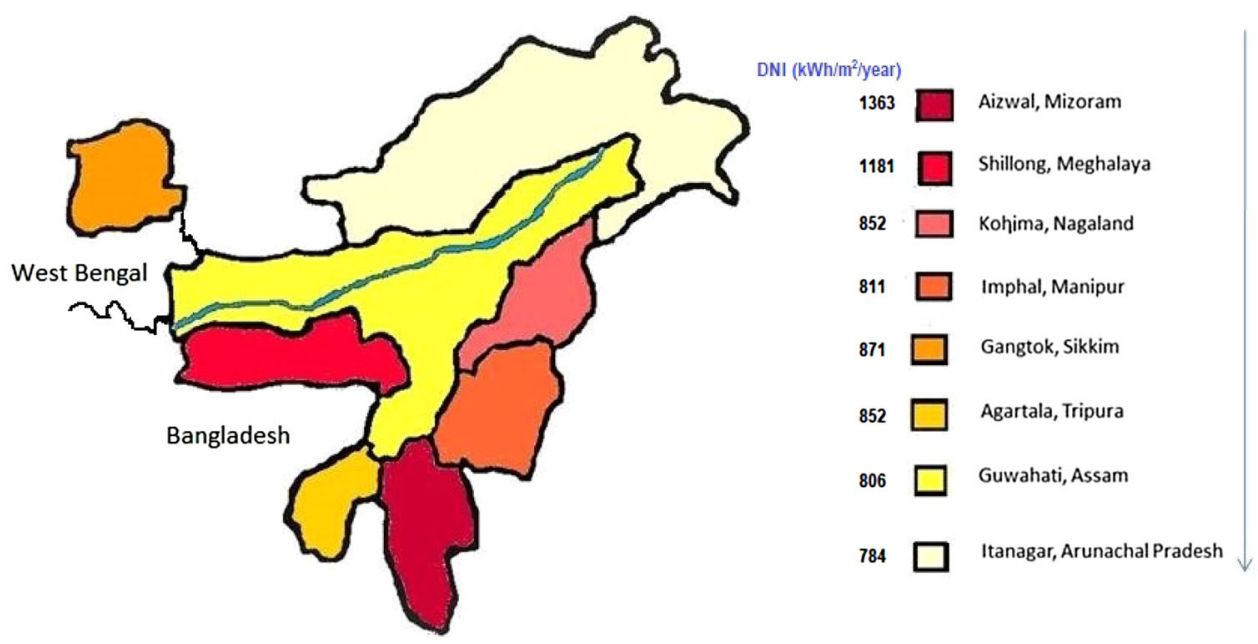

Figure 7. Solar radiation map for North-East India. 


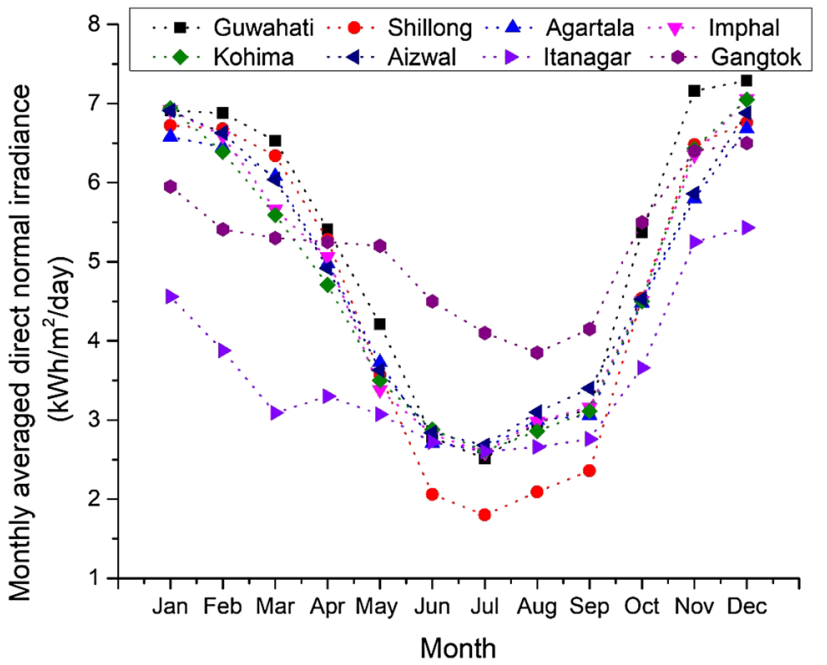

Figure 8. Monthly averaged DNI.

of November till March. For Itanagar, though the curve is almost uniform, it usually receives the lowest amount of direct normal radiation compared to the other places.

The seasonal distribution of the solar resource in Northeast India is uneven and has to be considered for planning in electricity grid management by the utilities once electric power generated by PV becomes significant as compared to the total amount of the electricity production [60]. Figure 9 shows the monthly average amount of the total solar radiation incident on a horizontal surface on the surface of the earth for a given month, the averaged value for that month is taken as the monthly averaged insolation incident on a horizontal surface or DHI. It is observed from figure 9 that for all the places (except Gangtok, Itanagar and Shillong) the trend of the monthly average total solar radiation is similar. The curves slowly increase initially from the months of January-February to attain a maximum value in the months of March-April and then begin to decrease until these attain an almost uniform trend with little deviations during the later months of the year. The values for Itanagar are comparatively lower, being a mountainous place. The values are the lowest for Shillong, especially during the months of June-September, i.e., the peak monsoon seasons during which time, this place remains almost heavily aboded by clouds and rainfall.

Clearness index is defined as the fraction of the solar radiation at the top of the atmosphere that reaches the surface of the earth after different reflection and absorption losses. The monthly average amount of the total solar radiation incident on a horizontal surface at the surface of the earth when the cloud cover is less than $10 \%$ divided by the monthly average incoming extra-terrestrial insolation for a given month, averaged for that month is taken as the monthly averaged clear sky insolation Clearness index. It can be observed from figure 10 that the curves are almost uniform for all the places and the trend line is almost linear. The values of Clearness index of Guwahati are lower than that of other places considered; the curve shows deviations from the normal trend. It shows a decreasing trend in the middle during the period of June-September. This behaviour is due to the rainy season which occurs in the region during this time and cloud remains in the sky for most of the time. A similar trend is also observed for Gangtok.

Figures 11 and 12 show the monthly averaged daylight hours and daily sunshine hours, respectively for different locations of NE India. The daylight hour is an important parameter because it depicts the length of day with change in time and month. Furthermore, it determines the period

Table 3. Average temperature and rainfall of various capital cities of North-eastern states.

\begin{tabular}{|c|c|c|c|c|c|c|c|c|c|c|c|c|}
\hline Parameters & Jan & Feb & Mar & Apr & May & Jun & Jul & Aug & Sep & Oct & Nov & Dec \\
\hline \multicolumn{13}{|c|}{ Avg. Temp $\left({ }^{\circ} \mathrm{C}\right)$} \\
\hline Guwahati & 17.5 & 19.5 & 23.3 & 26 & 26.8 & 28.1 & 28.9 & 29 & 28.6 & 26.2 & 22.5 & 18.7 \\
\hline Shillong & 10.4 & 12.3 & 16.4 & 18.9 & 19.6 & 20.8 & 21.2 & 21.1 & 20.5 & 18.1 & 14.4 & 11.4 \\
\hline Agartala & 18.7 & 21.4 & 25.5 & 27.9 & 28.4 & 28.1 & 28.1 & 28.3 & 28.5 & 27.2 & 23.7 & 20.1 \\
\hline Itanagar & 15.2 & 17.2 & 20.7 & 23.1 & 24.9 & 26.9 & 27.4 & 27.5 & 26.7 & 24.2 & 20 & 16.3 \\
\hline Kohima & 11.2 & 12.7 & 16.3 & 19 & 20.6 & 21.7 & 22 & 21.9 & 21.4 & 19.3 & 15.4 & 12 \\
\hline Imphal & 14.5 & 16.3 & 19.9 & 22.8 & 24 & 24.6 & 24.5 & 24.6 & 24.1 & 22.8 & 19 & 15.6 \\
\hline Aizwal & 15.8 & 17.4 & 20.9 & 22.5 & 22.5 & 22.7 & 22.7 & 22.8 & 22.5 & 21.9 & 19.3 & 16.7 \\
\hline Gangtok & 9.9 & 11.2 & 14.7 & 17.5 & 19.2 & 20.4 & 20.7 & 20.7 & 20.3 & 18.1 & 14.1 & 11.2 \\
\hline \multicolumn{13}{|c|}{ Precipitation/Rainfall (mm) } \\
\hline Guwahati & 12 & 16 & 60 & 141 & 278 & 315 & 313 & 261 & 181 & 100 & 15 & 6 \\
\hline Shillong & 13 & 17 & 79 & 180 & 403 & 851 & 696 & 480 & 387 & 234 & 37 & 8 \\
\hline Agartala & 12 & 20 & 63 & 154 & 269 & 462 & 382 & 329 & 231 & 178 & 43 & 3 \\
\hline Itanagar & 28 & 32 & 104 & 164 & 436 & 482 & 489 & 438 & 325 & 156 & 27 & 13 \\
\hline Kohima & 16 & 25 & 53 & 86 & 180 & 341 & 381 & 363 & 244 & 135 & 32 & 7 \\
\hline Imphal & 20 & 30 & 79 & 86 & 164 & 355 & 267 & 249 & 149 & 157 & 22 & 3 \\
\hline Aizwal & 12 & 28 & 81 & 151 & 268 & 524 & 442 & 435 & 336 & 230 & 47 & 10 \\
\hline Gangtok & 17 & 18 & 52 & 94 & 169 & 473 & 696 & 553 & 388 & 99 & 14 & 5 \\
\hline
\end{tabular}




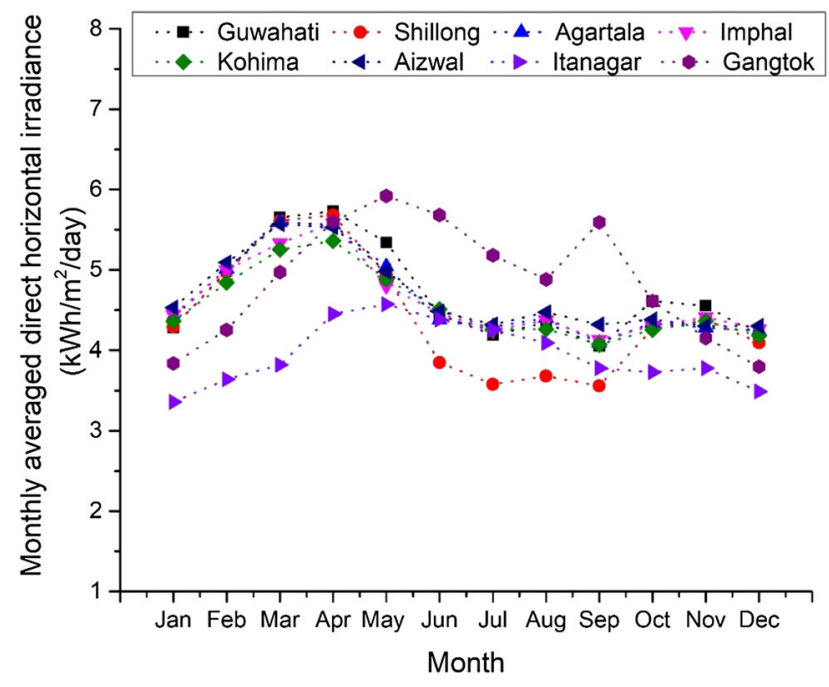

Figure 9. Monthly averaged insolation incident on a horizontal surface.

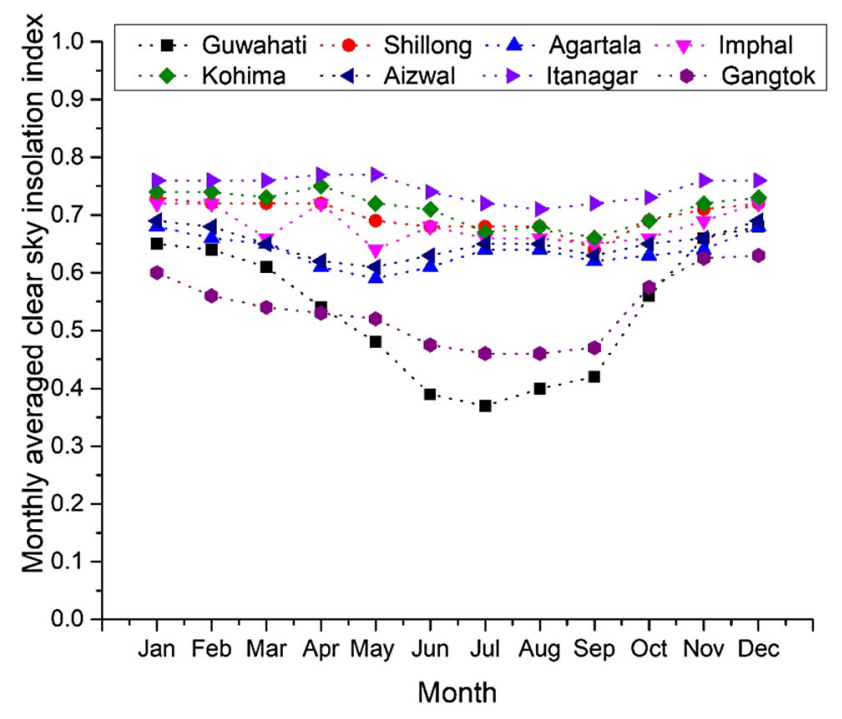

Figure 10. Monthly averaged clear sky insolation Clearness index.

during which sun is available for irradiation. It is observed from figures 11 and 12 that the daylight hours for all the places are almost the same and follow a similar trend. NE states of India are on the Northern hemisphere where summer occurs during the month of April to August and winter occurs from November to February. It can be observed that all the state capitals attain higher value of daylight hours during summer and it decreases from sunrise to sunset for summers too.

Wind speeds were measured at a height of $50 \mathrm{~m}$ above the ground. Each monthly averaged value was evaluated as the numerical average of 3-hourly values for the given month. It is evident from figure 13 that the wind speed varies for different places. The wind speed values are the highest for Gangtok, being on the Himalayan range. For

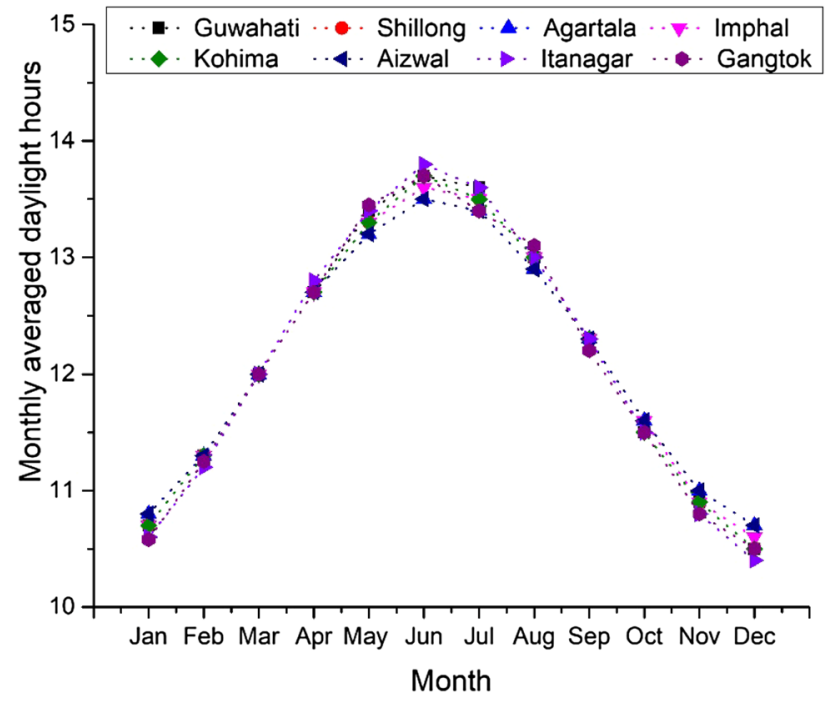

Figure 11. Monthly averaged daylight hours.

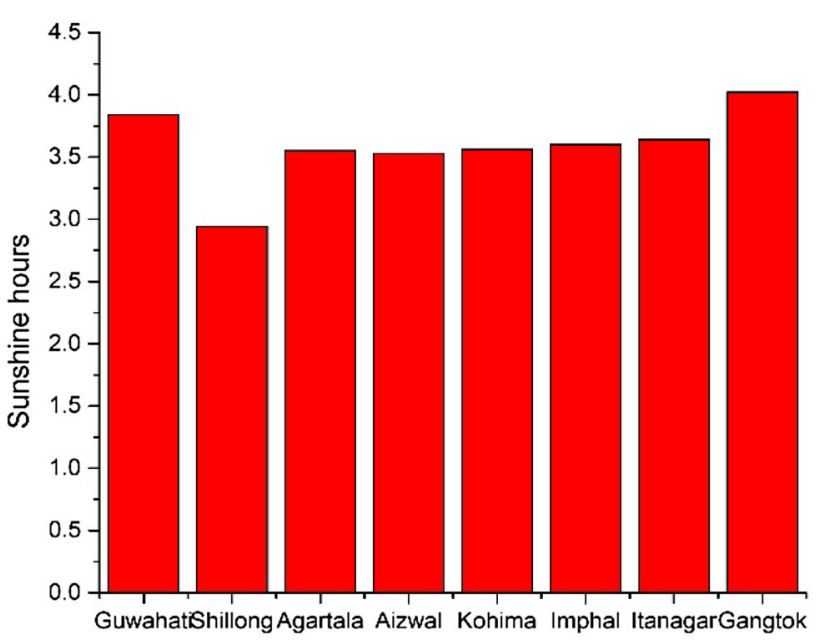

Figure 12. Daily sunshine hours [61].

Itanagar and Guwahati, wind speeds are also high. It is observed that the wind speed is more in the months of January-April and then it follows a slightly decreasing trend for these two places and again increases towards the end of the year. For other places, the wind speed is almost uniform over the year with slight variations. The wind speed trend is dictated by the pressure variation in the area. The pressure during the winter months is high in the region. The pressure slowly dissipates in March and April and reaches lower values during the summer months. The area experiences the lowest pressure in the month of July when monsoon is in its full vigour. In the month of March strong unpleasant winds come from the west and raise up clouds of sands. These winds mark a slow dissipation of high pressure over the area and become furious in the late April and early May and 




Figure 13. Monthly averaged wind speed.

prevail for a week or so with the same velocity. The mild winds blow from northeast to southeast during the months of winter season and thereafter this mild wind system is gradually replaced by the monsoon wind system from June to September which flows from southwest to northeast. By the end of the rainy season wind blows northeast due to retreat of the southwest monsoon.

The monthly averaged relative humidity remains low during the winter months (December-February) but becomes maximum in the summer months of June and July due to a higher rate of precipitation in the region. The atmosphere saturated with moisture particles experiences a low temperature during dry winter nights. During summer the monsoon wind overladen with water particles increases the humidity of the area. The monthly averaged relative humidity curves for all the locations follow the same trend as shown in figure 14. The relative humidity is maximum for Gangtok in June and July, but it also reaches a minimum during the winter among the mentioned locations. It has been reported that with an increase in the relative humidity, the efficiency decreases [62]. The degree reduction of electrical efficiency of PV due to an increase in the relative humidity is different for different solar cell material [63].

The power output of a PV plant reduces with an increase in its operating temperature. A constant wind throughout the year in NE region helps in natural cooling of a PV surface. A high wind velocity also lowers the relative humidity and thus reduces the chance of dust deposition on a PV surface, which finally improves the output of modules. However, wind sometimes causes dust scattering. This problem is again solved naturally by frequent rainfall in the region which naturally cleanses PV surfaces. From the climatic parametric study, it is observed that NE region is climatically suitable for a large PV plant installation and this fact has been verified through the economic study carried out in the later part of the present study.

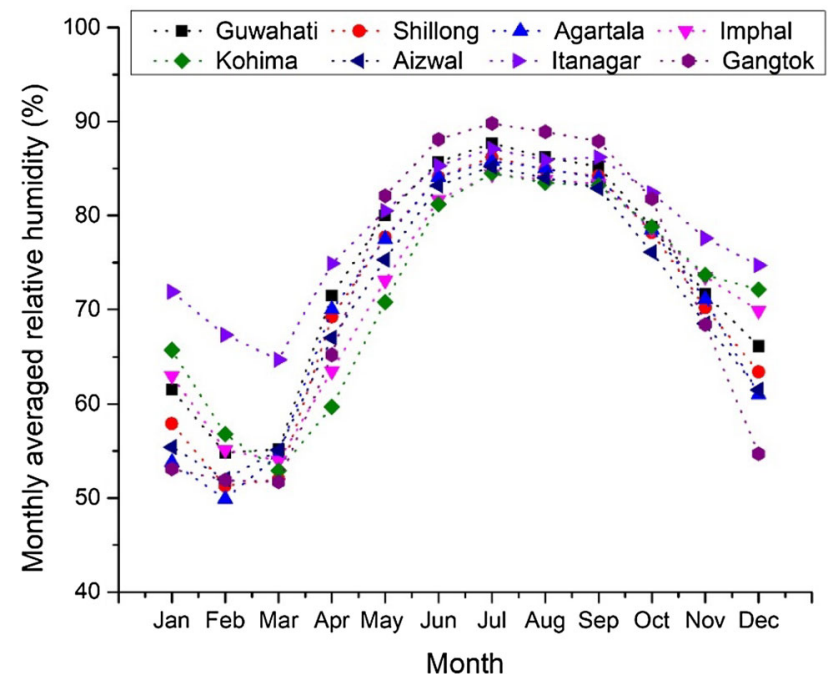

Figure 14. Monthly averaged relative humidity.

As shown in table 3, which represents data for the given period of years, the rainfall or precipitation rate is higher comparatively in the places, such as, Agartala and Aizawl. Gangtok receives the lowest amount of annual daily average rainfall. For Guwahati, the rainfall is approximately $4.5-5.0 \mathrm{~mm} /$ day. Shillong, the capital city of Meghalaya, also receives a good amount of rainfall during the entire year. It can be concluded that NE India receives an ample amount of rainfall during the summer season which may be advantageous in getting a higher performance of solar photovoltaic systems, because it helps in natural cleaning of PV module surface [64] and also cools the surface thus allowing the maximum solar energy conversion. A complete geographical and climatic description for the NE state capitals is presented in table 4 . The NE region is the home of extremely diverse mosaic of ethnic groups having distinctive social, cultural and economic identity. There are hundreds of races, tribes and their sub-groups in this region. Geographically, apart from Brahmaputra, Barak (Assam) and Imphal (Manipur) valleys and some flat lands in between the hills of Meghalaya and Tripura, two-thirds of the area of the region consists of a hilly terrain.

In the following section, a complete theoretical procedure for the design of a solar photovoltaic system is discussed and the climatic data available for these regions are used for calculation as well as for the performance evaluation of the system.

\subsection{Theoretical design of a $2 \mathrm{MW}$ grid connected solar PV plant}

Grid-connected solar PV system is a power generating method using PV arrays, where the produced electricity can be utilized in two different ways: in the first way produced energy is primarily supplied to a specific load and the 


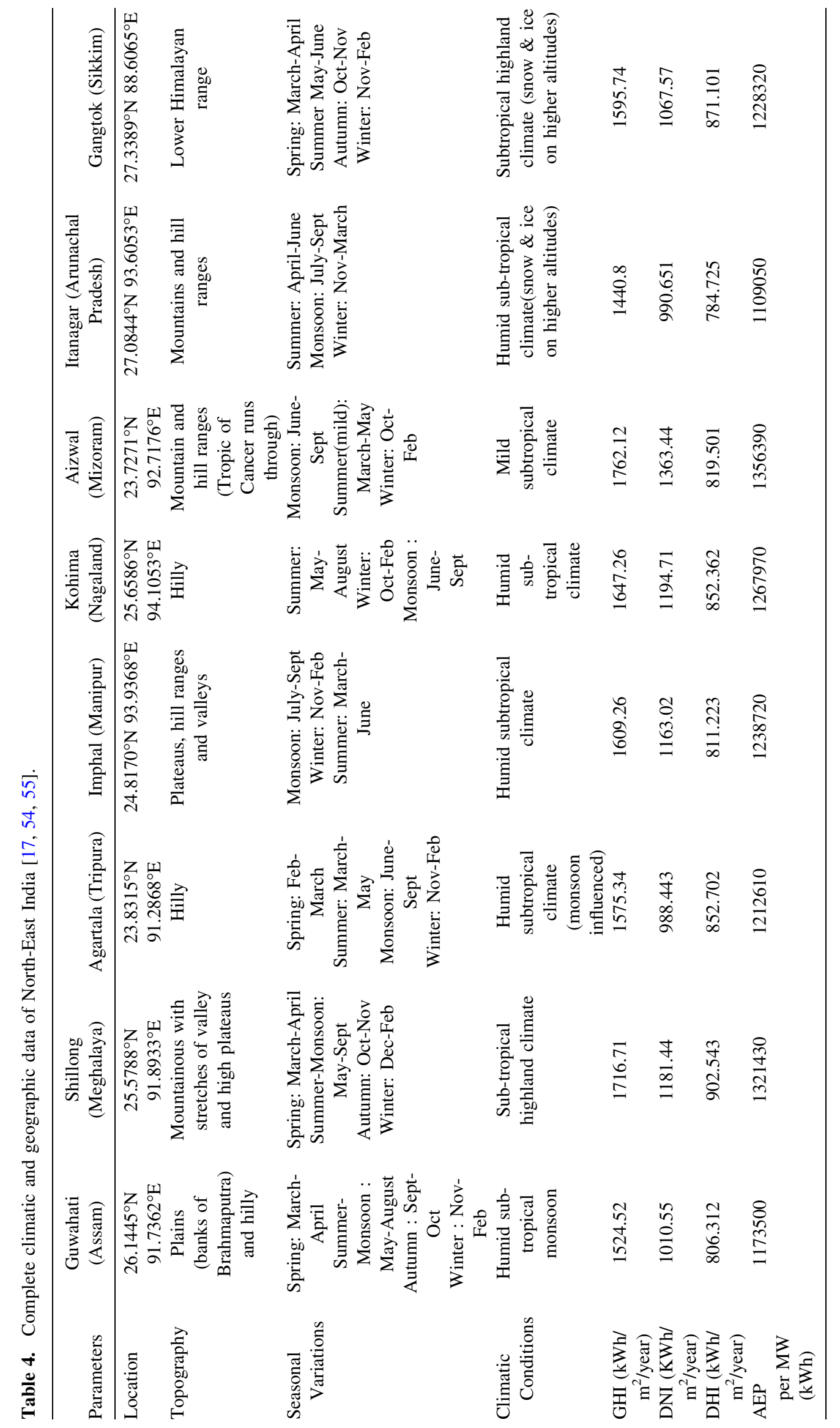


Table 5. Specifications of module [68].

Electrical parameters at standard test conditions (STC)

\begin{tabular}{lcccccc}
\hline $\begin{array}{l}\text { Power } \\
\text { output }(\mathrm{W})\end{array}$ & $\begin{array}{c}\text { Module } \\
\text { efficiency }(\eta \%)\end{array}$ & $\begin{array}{c}\text { Voltage at } \mathrm{P}_{\mathrm{MAX}} \\
\mathrm{V}_{\mathrm{MPP}}(\mathrm{V})\end{array}$ & $\begin{array}{c}\text { Current at } \mathrm{P}_{\mathrm{MAX}} \\
\mathrm{I}_{\mathrm{MPP}}(\mathrm{A})\end{array}$ & $\begin{array}{c}\text { Open-circuit voltage } \\
\mathrm{V}_{\mathrm{OC}}(\mathrm{V})\end{array}$ & $\begin{array}{c}\text { Short-circuit } \\
\text { current } \mathrm{I}_{\mathrm{SC}}(\mathrm{A})\end{array}$ & $\begin{array}{c}\text { Power } \\
\text { tolerance }(\mathrm{W})\end{array}$ \\
\hline 300 & 15.10 & 36.6 & 8.20 & 44.8 & 8.71 & $0 \sim+5$ \\
\hline
\end{tabular}

Temperature coefficient characteristics

\begin{tabular}{lcccr}
\hline $\begin{array}{l}\text { NOCT } \\
\left({ }^{\circ} \mathrm{C}\right)\end{array}$ & $\begin{array}{c}\text { Module efficiency } \\
\left(\% /{ }^{\circ} \mathrm{C}\right)\end{array}$ & $\begin{array}{c}\text { Temperature coefficient of } \\
P_{M A X}\left(\% /{ }^{\circ} \mathrm{C}\right)\end{array}$ & $\begin{array}{c}\text { Temperature coefficient of } \\
V_{O C}\left(\% /{ }^{\circ} \mathrm{C}\right)\end{array}$ & $\begin{array}{c}\text { Temperature coefficient of } \\
I_{S C}\left(\% /{ }^{\circ} \mathrm{C}\right)\end{array}$ \\
\hline $47 \pm 2$ & $-0.06 \pm 0.01$ & -0.4048 & -0.2931 & -0.0442 \\
& & & - & - \\
\hline
\end{tabular}

Table 6. Technical specifications of inverter [69].

\begin{tabular}{lccc}
\hline Input Data (DC) & & & \\
\hline Max. DC Power & Max. DC Voltage & Max. DC Current & MPP(T)Voltage Range \\
\hline $280 \mathrm{~kW}$ & $900 \mathrm{~V}$ & $600 \mathrm{~A}$ & $425-975 \mathrm{~V}$ \\
\hline Output Data (AC) & & & Max. AC Current \\
\hline Max. AC Power & Output AC Voltage Range & 540 A & Max. Efficiency \\
\hline $250 \mathrm{~kW}$ & $270-330 \mathrm{~V}$ & $98.3 \%$ \\
\hline
\end{tabular}

excess energy to the grid, whereas in the second way, complete energy is injected into the grid [65]. For achievement of the best performance, uniformity in connection of all the modules is quite essential. The desired current and voltage outputs of the array can be achieved from a combination of series and parallel connections [35]. PV modules are connected in series (series-connected arrangement is called strings) to achieve the desired voltage and these strings are connected in parallel to form a PV array to provide the desired current. These PV arrays are connected to inverter which transforms DC power into AC power. These may be mounted on ground or rooftops. The generated power is then fed directly to the grid without the use of battery storage system as in a stand-alone system. As there are no energy storage losses, utilization of power is effective in a grid-connected system but careful preparation and array-inverter sizing is required in order to get an optimal performance $[66,67]$. Furthermore, there are some grid-level costs associated in a PV power plant. These are, however, not considered in the present study.

Design of grid-connected system consists of several steps. Of these, PV array inverter matching is one of the prominents. TP 300 series 72 cell multi-crystalline PV modules manufactured by TATA Power Solar and BonfiglioliVectron GmbH RPS450-280 TL inverter are considered in the study. RPS TL series inverters are grid-coupled solar inverters used for feeding the power generated by PV modules to the medium voltage grid. The specifications of modules and inverters considered for this study are presented in tables 5 and 6.

Performance of PV module depends mainly on two parameters, firstly the solar insolation and secondly the module temperature [70]. The rating of the solar module presented in table 5 is measured under the standard test conditions (i.e., solar insolation of $1000 \mathrm{~W} / \mathrm{m}^{2}$, temperature of $25^{\circ} \mathrm{C}$ and air mass ratio of 1.5 ). However, in practice, there are possibilities that the solar irradiance can reach a value higher than $1000 \mathrm{~W} / \mathrm{m}^{2}$ which results in a temperature rise of the module and subsequently reduces the conversion efficiency. Therefore, to evaluate the actual performance of a PV system, it is important to determine the operating temperature of the PV module. By knowing the ambient temperature of a particular location, NOCT (Nominal Operating Cell Temperature) of the PV module and the incident solar radiation at that location [71] the module operating temperature can be calculated as

$$
T_{o p}=T_{a m b}+\frac{(N O C T-20)}{800} \times G
$$

The solar intensity $(G)$ in the equation (1) can be neglected and operating temperature can be calculated only by considering the ambient temperature of the location and specified NOCT [71] which is presented in equation (2).

$$
T_{o p}=T_{a m b}+(N O C T-20) \times G
$$


The deviation of the operating temperature from $25^{\circ} \mathrm{C}$, results in changes of the power output of the module. Considering the temperature correction, the module output power can be calculated as

$$
P_{T C}=P_{S T C}\left[1-\left(T_{o p}-T_{S T C}\right) \times \gamma_{p}\right]
$$

In the design of a grid-connected PV system, it is important to find out the most appropriate combination of module and inverters by considering the local operating conditions to maximize the power output and also keeping the economics of the plant on the positive side. The voltage, current and power ratings, of module and inverter are the three criteria which ensures a proper matching of the system in terms of performance and safety [66]. The first step of matching PV modules with inverter is to determine the lower and upper limits of a string, i.e., minimum and maximum numbers of modules to be connected in series. It has already been discussed that the operating temperature of the module plays an important role in matching PV array with the inverter. The output voltage of a PV generator is a function of operating temperature. A variation in the ambient temperature has a direct influence on the voltage output of PV system [66, 67, 72]. Therefore, it is necessary to calculate the maximum and minimum operating temperatures in order to estimate the maximum and minimum effective voltage of the module. The maximum operating temperature $\left(T_{o p}\right)_{\max }$ and the minimum operating temperature $\left(T_{o p}\right)_{\min }$ can be calculated by using Equations (1) and (2) and considering the recorded highest and lowest ambient temperatures of a particular location. Keeping in mind that the output voltage of the array should not fall outside the inverter's MPPT voltage range [66]. The minimum and maximum effective voltage of PV array can be calculated using the following Equations (4) and (5).

$$
\begin{aligned}
& V_{\text {Min-Eff }}=V_{M P-S T C}-\left[\gamma_{p} \times\left\{\left(T_{o p}\right)_{\max }-T_{S T C}\right\}\right] \\
& V_{\text {Max-Eff }}=V_{O P-S T C}-\left[\gamma_{p} \times\left\{\left(T_{o p}\right)_{\max }-T_{S T C}\right\}\right]
\end{aligned}
$$

The minimum number of modules in a string $\left(M_{\text {String }}\right)_{\min }$ and the maximum number of PV modules in a string $\left(M_{\text {String }}\right)_{\max }$ can be calculated using Equations (6) and (7), respectively. There is a voltage drop, which occurs when the generated electricity flows from an array to inverter. Therefore, during the calculation of the lower limit, a $2 \%$ voltage drop needs to be considered for the minimum effective voltage and a safety margin of $10 \%$ should be considered for the minimum DC input voltage $\left(V_{I n v-D C}\right)_{\min }$ of the inverter. Similarly, for the calculation of maximum effective voltage, an open-circuit voltage is considered since there is no voltage drop. But for the calculation of the maximum DC input voltage $\left(V_{I n v-D C}\right)_{\max }$, a safety margin of $5 \%$ is applied [66].

$$
\begin{aligned}
& \left(M_{\text {String }}\right)_{\min }=\frac{\left(V_{I n v-D C}\right)_{\min }}{V_{\text {Min-Eff }}} \\
& \left(M_{\text {String }}\right)_{\max }=\frac{\left(V_{\text {Inv-DC }}\right)_{\min }}{V_{\text {Max }-E f f}}
\end{aligned}
$$

In the next step, current rating of the module is matched with the inverter's input current rating in order to determine the maximum possible strings to be connected in parallel with the inverter. Due to a variation in the operating temperature, the value of the short-circuit current of the module also differs from its STC value, which can be determined as

$$
I_{S C-E f f}=I_{S C-S T C}-\left[\gamma_{I_{S C}} \times\left\{\left(T_{o p}\right)_{\max }-T_{S T C}\right\}\right]
$$

The maximum number of strings to be connected in parallel $(S)_{\max }$ with the inverter can be determined using the following Equation (9)

$$
(S)_{\max }=\frac{I_{I n v-D C}}{I_{S C-E f f}}
$$

The sizing of PV array and inverter for grid connected system depends on the rated capacity of PV array at STC, geographical location, environmental conditions and losses in inverter, converter, transformer and power cables [38]. To obtain the maximum output power from the inverter, it is necessary to provide an optimal output from the PV array which would be closest to the value of the input power rating of the inverter. It should be kept in mind that the PV array output power should not exceed the rated input power of the inverter. This step enables us to determine an optimal number of strings to be connected in parallel with the inverter by which the total number of modules can be estimated. Design of a 2 MW power plant for North-eastern part of India is being done in this study to understand the step-wise calculations mentioned above. Equations (1) and (2) are used to determine $\left(T_{o p}\right)_{\max }$ and $\left(T_{o p}\right)_{\min }$ for this location considering the maximum and minimum ambient temperatures and found to be $60{ }^{\circ} \mathrm{C}$ and $0{ }^{\circ} \mathrm{C}$, respectively. The minimum and minimum temperatures used for the design are taken based on the survey of historical temperature data of the locations considered in the study. Using the modules and inverter specification mentioned in tables 5 and 6 and applying Equations (4)-(7), $\left(M_{\text {String }}\right)_{\min }$, $\left(M_{\text {String }}\right)_{\max }$ and $(S)_{\max }$ are calculated to be 16,17 and 69 , respectively. The inverters considered for the study have an output power rating of $250 \mathrm{~kW}$ with the allowable maximum output power of $280 \mathrm{~kW}$. Hence a total of 8 inverters are required to obtain a power output of $2 \mathrm{MW}$. Table 7 presents the best possible array configurations for the plant.

Thus, it is evident from table 7 that the best possible arrangement of PV array for one inverter is 58 number of strings comprising 16 number of modules in a string. As the power output obtainable from this arrangement is $278.40 \mathrm{~kW}$ that matches closely with the maximum input DC power of the inverter (i.e., $280 \mathrm{~kW}$ ), this arrangement 
Table 7. Different possible arrangements of module array.

\begin{tabular}{lcc}
\hline $\begin{array}{l}\text { No. of modules per } \\
\text { string }\end{array}$ & $\begin{array}{c}\text { No. of strings per } \\
\text { array }\end{array}$ & $\begin{array}{c}\text { Total power output } \\
(\mathrm{kW})\end{array}$ \\
\hline$\left(M_{\text {String }}\right)_{\min }=16$ & 59 & 283.20 \\
& 58 & 278.40 \\
$\left(M_{\text {String }}\right)_{\max }=17$ & 57 & 273.60 \\
& 55 & 280.50 \\
& 54 & 275.40 \\
& 53 & 270.30 \\
\hline
\end{tabular}

can be selected for design. Hence, the total numbers of modules required for a $2 \mathrm{MW}$ power plant is estimated to be 7424. However, for the current study, complete designs of the power plant for all the NE state capitals along with performance and economic evaluation have been performed based on a simulation software, which are discussed in the following sections.

The selection of a proper cable size is the next crucial step in power plant design after the matching PV array and inverter is done. This is necessary in order to avoid excessive voltage drop or power loss in a plant. The Current Carrying Capacity is the most important parameter to be considered while selecting the cables which measure the maximum amount of current a conductor can have flowing through it without causing damage. In the present work, cable length calculation is not included. However, the following formulas can be used in order to determine the cross sectional area of the wire:

$$
\begin{gathered}
A_{\text {DCcable }}=\frac{2 \times L_{D \text { Ccable }} \times I_{D C} \times \rho}{\text { Loss } \times V_{M P \text { string }}} \\
A_{A \text { Ccable }}=\frac{2 \times L_{A \text { Ccable }} \times I_{A C} \times \rho \times \cos \phi}{\text { Loss } \times V_{A C}}
\end{gathered}
$$

\subsection{Simulation of $2 M W$ solar $P V$ power plant}

For an optimum sizing of the PV system, it is necessary to depend on simulation results obtained using an appropriate software. This will not only provide the performance of the complete system but also help a designer to predict the amount of energy that will be produced by the system on the basis of the local solar radiation statistics. Different simulation tools are used by different researchers for predicting performance of solar PV power plants. Senol et al [44] carried out simulations using PV*SOL tool for a solar PV system of varying capacity from 450 to $1250 \mathrm{kWp}$. A simulation study using TRNSYS simulation was performed by Ayadi et al [73] to assess the techno-economic performance of a grid connected photovoltaic system for University of Jordan. Kumar and Sudhakar [74] evaluated a 10 MW grid connected solar PV power plant in India and compared with simulated results obtained from PVsyst and PV-GIS software. Rashwan et al [75] performed a comparative study between electric grid based electricity supply and solar PV base electric supply using RETScreen (version 4.0) software. The authors recommended to install a solar PV system in countries with high electricity rates [75]. A 10 MW installed capacity grid-connected PV power plant was analyzed by Rehman et al [76] using RETScreen simulation tool in terms of economic and environmental parameters, such as, energy yield and GHG emissions. In the present study, PVsyst V6.63 software developed by André Mermoud of University of Geneva is used to evaluate a grid-connected PV system of $2 \mathrm{MW}$ capacity proposed for the North-eastern states of India. A literature review on the performance and feasibility assessment of solar PV system using PVsyst simulation tool has been carried out. Kumar et al [77] analyzed performance of a $100 \mathrm{kWp}$ grid connected PV system using $P V$ syst simulation tool. Barua et al [78] used PVsyst software to design and evaluate a rooftop PV system for the academic campus of Pondicherry University. A comparative performance assessment has been conducted using PVsyst simulation tool by Karki et al [79]. Two different cities, i.e., Kathmandu and Berlin were considered for the study and energy yield and overall losses were discussed [79]. Sharma et al [80] analyzed a $190 \mathrm{kWp}$ grid-connected PV system by comparing the practical results with simulated results obtained from PVsyst software. Okello et al [81] simulated the performance of a $3.2 \mathrm{kWp}$ grid-connected PV system using PVsyst software and compared the measured data with simulated results. From the above-mentioned reported studies, it has been observed that PVsyst is one of the widely used software tool for design of PV systems.

Therefore, in this study PVsyst has been used to assess the PV power generation potential of NE India. All the eight North-eastern state capitals are considered for the study to evaluate the potential of these states for installing grid connected solar PV system and results are compared. The meteorological data necessary for the simulation, viz., global radiation, diffuse radiation, ambient temperature and wind speed are taken from NASA which covers a period of 22 years (July 1983-June 2005). In order to harness optimum radiation, tilting angle (slope) for the simulation is taken as the latitude of individual location as shown in table 8 and the orientation is considered as $0^{\circ}$ azimuth (facing due south) without shading [82]. Solar modules and inverter mentioned in the above theoretical discussions are also considered for the simulation. Simulation is carried out considering albedo, usual operating temperature (under $1000 \mathrm{~W} / \mathrm{m}^{2}$ ) and limit overload losses are considered as $0.2,50{ }^{\circ} \mathrm{C}$ and $3 \%$, respectively, for all the locations. Reference temperatures for array design with respect to the inverter input voltage is an important parameter to be considered during the simulation, which are site dependent and presented in table 8. For calculation of maximum and minimum voltage record lowest temperature and record maximum temperature observed during last 20 years are considered [83]. 
Table 8. Design parameters.

\begin{tabular}{|c|c|c|c|c|c|c|c|c|}
\hline Location & Guwahati & Shillong & Agartala & Imphal & Kohima & Aizawl & Itanagar & Gangtok \\
\hline Tilt angle & $26^{\circ}$ & $25^{\circ}$ & $23^{\circ}$ & $24^{\circ}$ & $25^{\circ}$ & $23^{\circ}$ & $27^{\circ}$ & $27^{\circ}$ \\
\hline Operating Temperature $\left({ }^{\circ} \mathrm{C}\right)$ for $V_{M i n-m p p}$ & 60.6 & 50.2 & 62.2 & 55.7 & 53.9 & 52.1 & 59.5 & 49.9 \\
\hline Operating Temperature $\left({ }^{\circ} \mathrm{C}\right)$ for $V_{M a x-m p p}$ & 1.5 & -3.3 & 2 & -2.7 & 1 & 3.2 & 5.2 & -2.2 \\
\hline$V_{\text {Min-mpp }}($ Volts $)$ & 31.3 & 32.9 & 31.2 & 32.0 & 32.3 & 32.6 & 31.4 & 32.9 \\
\hline$V_{\text {Max-mpp }}($ Volts $)$ & 48.1 & 48.8 & 48.1 & 48.8 & 48.3 & 48.0 & 47.7 & 48.7 \\
\hline Min. no of modules in a string & 14 & 13 & 14 & 14 & 14 & 14 & 14 & 13 \\
\hline Max. no of modules in a string & 18 & 18 & 18 & 18 & 18 & 18 & 18 & 18 \\
\hline
\end{tabular}

Table 9. Different possible arrangements.

\begin{tabular}{lcc}
\hline $\begin{array}{l}\text { No. of modules } \\
\text { per string }\end{array}$ & $\begin{array}{c}\text { No. of strings } \\
\text { per array }\end{array}$ & $\begin{array}{c}\text { Total PV } \\
\text { array output }(\mathrm{kW})\end{array}$ \\
\hline 14 & 67 & 281.40 \\
& 66 & 277.20 \\
& 65 & 273.00 \\
15 & 63 & 283.500 \\
& 62 & 279.00 \\
& 61 & 274.50 \\
16 & 59 & 283.20 \\
& 58 & 278.40 \\
17 & 57 & 273.60 \\
& 55 & 280.50 \\
& 54 & 275.40 \\
18 & 53 & 270.30 \\
& 52 & 280.80 \\
& 51 & 275.40 \\
\end{tabular}

It is observed from table 9 that the minimum and maximum number of modules to be connected in series are 14 to 18 , respectively. In case of capital city of Sikkim (Gangtok) and Meghalaya (Shillong), the minimum number of modules is found to be 13 due to a low ambient temperature condition of the location as given in table 8 . It can be concluded that by connecting 15 modules in series with 62 parallel strings (total 496 strings for 8 inverters), it is possible to achieve $279 \mathrm{~kW}$ of PV array power which is closest to the input power of the inverter. This combination will result in an achievement of the maximum performance and an optimum cost. This module inverter arrangement obtained from simulation slightly differs with the theoretical results because in the simulation tool, voltage drop of $2 \%$ and safety margin of $10 \%$ are not considered for calculating the maximum and minimum effective voltages. The safe and permissible limit of the inverter current is also important from design point of view which is shown in table 10 considering the example of Guwahati (Assam). It can be observed from table 10 by that using the selected combination of PV module and inverter mentioned above, a maximum short circuit current of $4645 \mathrm{~A}$ (which is possible at a maximum solar radiation of $1064 \mathrm{~W} / \mathrm{m}^{2}$ ) is obtained, this value is within the permissible limit of inverter input current of $4800 \mathrm{~A}$. Hence, considering this inverter and module arrangement, further performance and financial analysis of the $2 \mathrm{MW}$ power plant in all NE state capitals is performed and presented in the following sections.

\subsection{Mounting and arrangement of the modules}

While designing a power plant, shading analysis is a crucial step in order to avoid any losses due to shades from nearby structures, objects, trees and nearby modules. Shading reduces the amount of irradiation to be actually received by the modules. Hasapis et al [37] reported that avoiding shading is an important issue because even a small area of shade may significantly reduce the output of a module or string of modules. Similarly, Castellano et al [84] reported that incomplete or improper shading of PV module resulted in a major loss in the power output and also discussed about

Table 10. Matching current rating of inverter.

\begin{tabular}{|c|c|c|c|c|c|c|c|c|c|c|}
\hline \multirow[b]{2}{*}{ Location } & \multirow[b]{2}{*}{$\begin{array}{l}\text { Module in } \\
\text { series }\end{array}$} & \multirow[b]{2}{*}{$\begin{array}{l}\text { Parallel } \\
\text { strings }\end{array}$} & \multirow[b]{2}{*}{$\begin{array}{l}\text { No. of } \\
\text { modules }\end{array}$} & \multirow[b]{2}{*}{$\begin{array}{l}\text { Array nominal } \\
\text { power }(\mathrm{kW})\end{array}$} & \multicolumn{3}{|c|}{ STC condition $\left(1000 \mathrm{~W} / \mathrm{m}^{2}\right)$} & \multicolumn{3}{|c|}{$\begin{array}{l}\text { Maximum irradiation } \\
\left(1064 \mathrm{~W} / \mathrm{m}^{2}\right)\end{array}$} \\
\hline & & & & & $\begin{array}{c}\text { Max. operating } \\
\text { power }(\mathrm{kW})\end{array}$ & $\begin{array}{l}\mathrm{I}_{\mathrm{mpp}} \\
(\mathrm{A})\end{array}$ & $\begin{array}{l}\mathrm{I}_{\mathrm{sc}} \\
(\mathrm{A})\end{array}$ & $\begin{array}{c}\text { Max. operating } \\
\text { power }(\mathrm{kW})\end{array}$ & $\begin{array}{l}I_{\mathrm{mpp}} \\
\text { (A) }\end{array}$ & $\begin{array}{l}\mathrm{I}_{\mathrm{sc}} \\
(\mathrm{A})\end{array}$ \\
\hline \multirow[t]{5}{*}{ Guwahati } & 14 & 528 & 7392 & 2218 & 1994 & 4327 & 4649 & 2121 & 4602 & 4945 \\
\hline & 15 & 496 & 7440 & 2232 & 2007 & 4065 & 4368 & 2134 & 4323 & 4645 \\
\hline & 16 & 464 & 7424 & 2227 & 2003 & 3803 & 4086 & 2130 & 4044 & 4346 \\
\hline & 17 & 432 & 7344 & 2203 & 1981 & 3540 & 3804 & 2107 & 3765 & 4046 \\
\hline & 18 & 408 & 7344 & 2203 & 1981 & 3344 & 3593 & 2107 & 3556 & 3821 \\
\hline
\end{tabular}


provision of an optimal spacing between the PV rows in order to avoid shading [84]. Deline et al [85] developed an analytical approximation model to predict the performance of a large PV system at partial shading condition and compared with experimental results. Moreover, module arrangement also determines the amount of area the plant requires and with proper module arrangement capital cost of the power plant can be reduced. The minimum distance between two solar modules (inter-row distance), which is to be maintained in order to prevent mutual shading is calculated using the following expressions [86, 87]

$$
\begin{gathered}
\sin \alpha=\sin \phi \times \sin \delta+\cos \phi \times \cos \delta \times \cos \omega \\
L_{S H}=\frac{\cos \psi=\frac{\cos \delta \times \sin \omega}{\cos \alpha}}{\tan \left[\sin ^{-1}(0.648 \cos \phi-0.399 \sin \phi)\right]} \\
D=L_{S H} \times \sin \theta \\
h=L \times \sin \theta
\end{gathered}
$$

The length of the shadow casted PV modules increases during the "low-sun" days or during winter season. Therefore, the worst-case shadow condition causing the longest shadow occurs during these days. This results in the lowest access to sunlight radiation during this period. The winter solstice, generally falls on $21^{\text {st }}$ or $22^{\text {nd }}$ of December, which gives the longest shadow length. In the present work it is taken as $22^{\text {nd }}$ December and used in the calculations [88].The local latitude angle for all the places is taken as the tilt angle in order to harness optimum radiation [82]. Since, India lies in the Northern hemisphere so the sun's elliptical trajectory moves from east to west having an inclination towards south and, hence to obtain the maximum quantity of solar energy the module is mounted towards due south [89]. Figure 15 presents the mounting of the solar modules.

The shading analysis is presented in table 11. It is observed that the maximum shadow length occurs at 8 a.m. $\left(\omega=-60^{\circ}\right)$ and evening 4 p.m. $\left(\omega=+60^{\circ}\right)$ for all the eight considered state capitals. It is observed that the intermodule distance between the modules should be in the

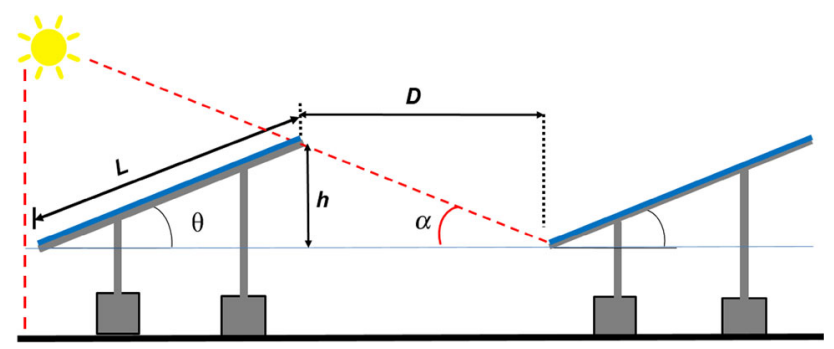

Figure 15. Pictorial description of the shading phenomena. range of $0.519-0.786 \mathrm{~m}$ in order to avoid shading. For the present study, the inter-row distance of PV array is considered using a simple thumb rule where the minimum spacing between the rows is equal to three times the height of module [90], i.e.,

$$
D=3 \times h
$$

For an estimation of cost associated with the land, it is important to calculate the total area required for the plant. Equation (15) is used to calculate the inter-row distance of the array. The maximum and minimum distances are estimated to be $2.70 \mathrm{~m}$ for tilt angle of $27^{\circ}$ and $2.32 \mathrm{~m}$ for tilt angle of $23^{\circ}$, respectively. The maximum inter-row distance $(D)$ of PV array is calculated to be $0.786 \mathrm{~m}$ for Gangtok, which is presented in table 11. Hence, In order to simplify the calculations, the maximum inter-row distance of the array is taken as $2.70 \mathrm{~m}$ for tilt angle of $27^{\circ}$. The plant layout and arrangement of the module in the PV field also plays a crucial role in determining the area of the plant. The number of modules required for the plant is 7440 . To achieve an uninterrupted functioning of the plant due to some unavoidable reasons of failure, modules are arranged in 8 sections and each section is connected to a single inverter. Arranging modules in this manner allows separate maintenance of individual sections without interrupting the power supply from running sections. The complete layout and arrangement of the modules is shown in figure 16. A single section includes 62 rows connected in parallel and each row contains 15 modules connected in series. A gap of $1.5 \mathrm{~m}$ is considered between the columns to ease the maintenance and cleaning process of the plant. Total area required for the proposed plant of $2 \mathrm{MW}$ is estimated to be $35796.254 \mathrm{~m}^{2}$ (8.845 acres). The detailed area calculation is presented in table 12 .

\subsection{Life cycle and economic assessment of the plant}

2.5a Life cycle evaluation: The life cycle evaluation (LCE) is a method for assessing different energy aspects related to the development of a system and its potential impact throughout its life [91]. This section presents the complete assessment of $2 \mathrm{MW}$ SPV power plant considered for the North-eastern state in terms of its electricity production factor (EPF), energy payback time (EPBT), life cycle conversion efficiency (LCCE), capacity utilization factor (CUF), net $\mathrm{CO}_{2}$ mitigation and carbon credits. Table 13 presents the formula and definitions of the parameters used for the calculation of various factors required for LCE. Tiwari et al [92] investigated the total embodied energy (life cycle energy input) associated with a PV module and found it to be $1516.59 \mathrm{kWh} / \mathrm{m}^{2}$ of module which is considered for the present study. The total embodied energy for the proposed plant is estimated to be $22386.32 \mathrm{MWh}$. For the calculation of $\mathrm{CO}_{2}$ emission, a standard value of 
Table 11. Shading analysis for NE states.

\begin{tabular}{|c|c|c|c|c|c|c|c|c|c|c|}
\hline Location & $\begin{array}{l}\text { Local time } \\
\text { Hour angle, } \omega\end{array}$ & $\begin{array}{l}8 \mathrm{am} \\
-60^{\circ}\end{array}$ & $\begin{array}{l}9 \mathrm{am} \\
-45^{\circ}\end{array}$ & $\begin{array}{c}10 \mathrm{am} \\
-30^{\circ}\end{array}$ & $\begin{array}{l}11 \mathrm{am} \\
-15^{\circ}\end{array}$ & $\begin{array}{c}12 \mathrm{pm} \\
0^{\circ}\end{array}$ & $\begin{array}{l}1 \mathrm{pm} \\
+15^{\circ}\end{array}$ & $\begin{array}{l}2 \mathrm{pm} \\
+30^{\circ}\end{array}$ & $\begin{array}{l}3 \mathrm{pm} \\
+45^{\circ}\end{array}$ & $\begin{array}{l}4 \mathrm{pm} \\
+60^{\circ}\end{array}$ \\
\hline \multirow[t]{4}{*}{ Guwahati } & $\sin \alpha$ & 0.23648 & 0.407 & 0.5379 & 0.62 & 0.648 & 0.62 & 0.5379 & 0.407 & 0.23648 \\
\hline & $\cos \varphi$ & -0.8177 & -0.7102 & -0.5442 & -0.3027 & 0 & 0.3027 & 0.5442 & 0.7102 & 0.8177 \\
\hline & $\left|L_{S H}\right|, m$ & 1.601 & 1.391 & 1.066 & 0.593 & 0 & 0.593 & 1.066 & 1.391 & 1.601 \\
\hline & $|D|, m$ & 0.702 & 0.610 & 0.467 & 0.260 & 0 & 0.260 & 0.467 & 0.610 & 0.702 \\
\hline \multirow[t]{4}{*}{ Shillong } & $\sin \alpha$ & 0.242 & 0.413 & 0.545 & 0.626 & 0.656 & 0.626 & 0.545 & 0.413 & 0.242 \\
\hline & $\cos \varphi$ & -0.88 & -0.71 & -0.55 & -0.305 & 0 & 0.305 & 0.55 & 0.71 & 0.88 \\
\hline & $\left|L_{S H}\right|, m$ & 1.631 & 1.316 & 1.019 & 0.565 & 0 & 0.565 & 1.019 & 1.316 & 1.631 \\
\hline & $|D|, m$ & 0.689 & 0.556 & 0.431 & 0.239 & 0 & 0.239 & 0.431 & 0.556 & 0.689 \\
\hline \multirow[t]{4}{*}{ Agartala } & $\sin \alpha$ & 0.2589 & 0.4327 & 0.566 & 0.6499 & 0.6785 & 0.6499 & 0.566 & 0.4327 & 0.2589 \\
\hline & $\cos \varphi$ & -0.823 & -0.7196 & -0.5564 & -0.3124 & 0 & 0.3124 & 0.5564 & 0.7196 & 0.823 \\
\hline & $\left|L_{S H}\right|, m$ & 1.334 & 1.166 & 0.902 & 0.506 & 0 & 0.506 & 0.902 & 1.166 & 1.334 \\
\hline & $|D|, m$ & 0.521 & 0.456 & 0.352 & 0.198 & 0 & 0.198 & 0.352 & 0.456 & 0.521 \\
\hline \multirow[t]{4}{*}{ Imphal } & $\sin \alpha$ & 0.2494 & 0.422 & 0.554 & 0.637 & 0.666 & 0.637 & 0.554 & 0.422 & 0.2494 \\
\hline & $\cos \varphi$ & -0.82 & -0.72 & -0.55 & -0.308 & 0 & 0.308 & 0.55 & 0.72 & 0.82 \\
\hline & $\left|L_{S H}\right|, m$ & 1.427 & 1.253 & 0.957 & 0.536 & 0 & 0.536 & 0.957 & 1.253 & 1.427 \\
\hline & $|D|, m$ & 0.580 & 0.510 & 0.389 & 0.218 & 0 & 0.218 & 0.389 & 0.510 & 0.580 \\
\hline \multirow[t]{4}{*}{ Kohima } & $\sin \alpha$ & 0.2412 & 0.4123 & 0.544 & 0.627 & 0.655 & 0.627 & 0.544 & 0.4123 & 0.2412 \\
\hline & $\cos \varphi$ & -0.82 & -0.71 & -0.55 & -0.304 & 0 & 0.304 & 0.55 & 0.71 & 0.82 \\
\hline & $\left|L_{S H}\right|, m$ & 1.524 & 1.319 & 1.022 & 0.565 & 0 & 0.565 & 1.022 & 1.319 & 1.524 \\
\hline & $|D|, m$ & 0.644 & 0.558 & 0.432 & 0.239 & 0 & 0.239 & 0.432 & 0.558 & 0.644 \\
\hline \multirow[t]{4}{*}{ Aizawl } & $\sin \alpha$ & 0.2599 & 0.434 & 0.567 & 0.651 & 0.6798 & 0.651 & 0.567 & 0.434 & 0.2599 \\
\hline & $\cos \varphi$ & -0.823 & -0.72 & -0.56 & -0.313 & 0 & 0.313 & 0.56 & 0.72 & 0.823 \\
\hline & $\left|L_{S H}\right|, m$ & 1.329 & 1.163 & 0.905 & 0.506 & 0 & 0.506 & 0.905 & 1.163 & 1.329 \\
\hline & $|D|, m$ & 0.519 & 0.454 & 0.353 & 0.198 & 0 & 0.198 & 0.353 & 0.454 & 0.519 \\
\hline \multirow[t]{4}{*}{ Itanagar } & $\sin \alpha$ & 0.227 & 0.396 & 0.526 & 0.608 & 0.636 & 0.608 & 0.526 & 0.396 & 0.227 \\
\hline & $\cos \varphi$ & -0.82 & -0.71 & -0.54 & -0.30 & 0 & 0.30 & 0.54 & 0.71 & 0.82 \\
\hline & $\left|L_{S H}\right|, m$ & 1.716 & 1.486 & 1.130 & 0.628 & 0 & 0.628 & 1.130 & 1.486 & 1.716 \\
\hline & $|D|, m$ & 0.779 & 0.675 & 0.513 & 0.285 & 0 & 0.285 & 0.513 & 0.675 & 0.779 \\
\hline \multirow[t]{4}{*}{ Gangtok } & $\sin \alpha$ & 0.223 & 0.394 & 0.523 & 0.604 & 0.632 & 0.604 & 0.523 & 0.394 & 0.223 \\
\hline & $\cos \varphi$ & -0.82 & -0.71 & -0.54 & -0.298 & 0 & 0.298 & 0.54 & 0.71 & 0.82 \\
\hline & $\left|L_{S H}\right|, m$ & 1.731 & 1.499 & 1.140 & 0.629 & 0 & 0.629 & 1.140 & 1.499 & 1.731 \\
\hline & $|D|, m$ & 0.786 & 0.681 & 0.518 & 0.286 & 0 & 0.286 & 0.518 & 0.681 & 0.786 \\
\hline
\end{tabular}

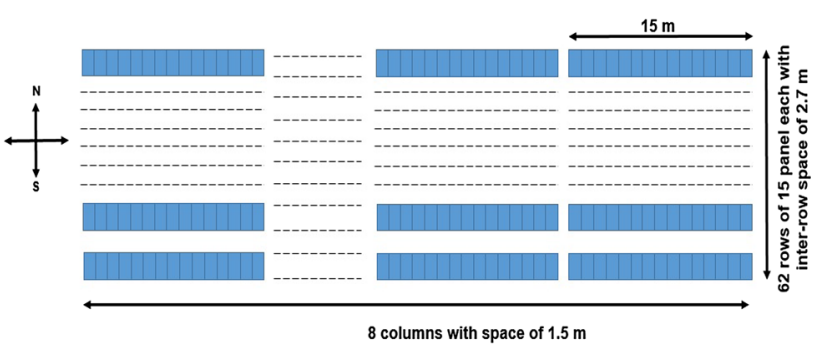

Figure 16. Module arrangement of PV plant.

$0.98 \mathrm{~kg}$ of $\mathrm{CO}_{2}$ per $\mathrm{kWh}$ is used. In the present study, considering the Indian conditions, the losses associated with transportation and distribution of electricity are incorporated and the $\mathrm{CO}_{2}$ emission per $\mathrm{kWh}$ is taken as $1.58 \mathrm{~kg}$ of $\mathrm{CO}_{2}$ [93]. The total $\mathrm{CO}_{2}$ emission of the proposed plant due to the embodied energy is calculated to be $3.537 \times 10^{7}$ tonnes of $\mathrm{CO}_{2}$.

2.5b Financial evaluation of the plant: Harnessing energy from sun is free, but to take advantage of this free energy, financial investment is required to set-up a system for converting solar radiation into useful electrical energy. In recent years, it has been observed that renewable energy market is rising all around the globe and contribution of solar energy to the renewable energy sector is significant. To sustain growth in this competitive world, market price plays an important role and therefore, financial evaluation of a system is important. Various economic tools used by the researchers as objective function are net present cost (NPC), net present value (NPV), levelized unit cost of electricity (LUCE), simple payback period (SPP) and discounted payback period (DPP) [94]. To check the economic feasibility of the plant, Net Present Value (NPV), Payback Period and unit cost of electricity for all the locations is evaluated and compared in the study. 
Table 12. Area calculation for 2 MW SPV power plant.

\begin{tabular}{lc}
\hline Particulars & Value \\
\hline $\begin{array}{l}\text { The dimension of } \\
\text { the TATA }\end{array}$ & $1.984 \times 1 \times 0.04$ \\
TP300 series \\
module $(m)$ \\
No of Modules \\
connected in \\
series to form \\
one row \\
Width of one row \\
$\begin{array}{l}\text { Total length of one } \\
\text { section }\end{array}$ \\
$\begin{array}{l}\text { Total area required } \\
\text { for one section }\end{array}$ \\
$\begin{array}{l}\text { Total area covered } \\
\text { by all sections }\end{array}$ \\
$\begin{array}{l}\text { Area covered by } \\
\text { space provided }\end{array}$ \\
$\begin{array}{l}\text { between sections } \\
\text { Total area required } \\
\text { for the proposed } \\
\text { power plant }\end{array}$ \\
\hline
\end{tabular}

NPV of a system can be defined as the difference between the present value of cash inflow and cash outflow including capital cost. A positive NPV implies a surplus showing that the money related position of the investor would be enhanced by attempting the undertaking. Clearly, a negative NPV would demonstrate a monetary misfortune. It can be expressed as

$$
N P V=\left(C_{\text {in }}\right)_{t}-\left(C_{\text {out }}\right)_{t}
$$

The net present inflow and outflow of a system can be determined as

$$
\left(C_{i n}\right)_{t}=\left(S_{A E G}\right)_{N P V}+\left(\mathrm{S}_{S V}\right)_{N P V}
$$

$$
\left(C_{\text {out }}\right)_{t}=C_{\text {cap }}+\left(C_{o \& m}\right)_{N P V}
$$

The project capital cost can be determined as [71]

$$
C_{c a p}=C_{m}+C_{l}+C_{e \& C}+C_{m s}+C_{i n v}+C_{e}+C_{m i s}
$$

TP 300 series multi-crystalline PV modules manufactured by TATA Power Solar is taken for designing the power plant. The solar module price is decreasing and the current market price for the solar modules in India is taken as INR 37 per $\mathrm{W}_{\mathrm{p}}$. BonfiglioliVectron GmbH RPS450-280 $T L$ inverter is considered with one inverter costing INR 4500000 [23]. The cost associated with erection, commissioning, mounting of structures, electrical connection and miscellaneous cost is presented in table 14. Due to varying cost of land purchase in NE states, the land cost is not incorporated in the economic assessment.

Operation and maintenance costs associated with the system is an important parameter in evaluating cost analysis. The present value of the operation and maintenance cost over the lifetime of the system $(n)$ can be determined using the following expression

$$
\left(C_{o \& m}\right)_{N P V}=\frac{\left(C_{o \& m}\right)_{a}}{(d-g)}\left[1-\left(\frac{1+g}{1+d}\right)^{n}\right]
$$

The discount rate is considered to be $9.75 \%$ [95] and the inflation rate $3.05 \%$ [96] in operation and maintenance cost. The life of the plant is considered as 25 years in the above calculations.

The annual electricity generated $S_{A E G}$ by the plant is calculated as

$$
S_{A E G}=C U F \times E_{\text {peak }} \times 8760 \times T_{e}
$$

The present value of saving from electricity generation of the lifetime and from salvage value is determined as

$$
\left(S_{A E G}\right)_{N P V}=\frac{S_{A E G}}{(d-g)}\left[1-\left(\frac{1+g}{1+d}\right)^{n}\right]
$$

Table 13. Parameters for life cycle evaluation (LCE) of a PV system.

\begin{tabular}{lc}
\hline Electricity production factor (EPF): Ratio of annual energy & $E P F=\frac{E_{\text {generated }}}{E_{\text {embodied }}}$ \\
generated by the system to the embodied energy & $E P B T=\frac{E_{\text {embodied }}}{E_{\text {generated }}}$ \\
Energy payback time (EPBT): Amount of time required to & $E_{\text {embodied }}=E_{\text {materials }}+E_{\text {manufacturing }}$ \\
recover the total energy input of the proposed plant. & $+E_{\text {transport }}+E_{\text {installation }}+E_{\text {o\&p }}$ \\
Embodied Energy: Amount of energy consumed by the system & $L C C E=\frac{E_{\text {generated }} \times L_{\text {plant }}-E_{\text {embodied }}}{E_{\text {solar }} \times L_{\text {plant }}}$ \\
components for their materials and manufacturing transportation & $C U F=\frac{E_{\text {generated }}}{E_{\text {peak }} \times 8760}$ \\
Life cycle conversion efficiency (LCCE): Net energy productivity of the & \\
system with respect to the solar energy (insolation) over the life time of the system & $\left(C O_{2}\right)_{n e t}=\left(C O_{2}\right)_{\text {in }} \times L_{\text {plant }}-\left(C O_{2}\right)_{e}$ \\
Capacity Utilization Factor (CUF): Ratio of energy output at & \\
real condition (actual energy) to energy output at ideal condition & \\
(peak energy) of the SPV over the yearly period & Net $\mathrm{CO}_{2}$ mitigation: Total carbon dioxide mitigation that the system \\
achieves over its life &
\end{tabular}


Table 14. Break-up cost of the PV plant.

\begin{tabular}{|c|c|c|}
\hline S1. No. & Particulars & Cost (INR) \\
\hline 1 & Module cost & $8,25,84,000$ \\
\hline 2 & Inverter cost & $3,60,00,000$ \\
\hline 3 & Mountings and structure & $2,00,00,000$ \\
\hline 4 & $\begin{array}{l}\text { Erection and commissioning cost } \\
\text { i. Foundation } \\
\text { ii. Construction } \\
\text { iii. Installation } \\
\text { iv. Fire and safety } \\
\text { v. Drainage } \\
\text { vi. Water supply }\end{array}$ & $67,50,000$ \\
\hline 5 & $\begin{array}{l}\text { Cost for electrical connection } \\
\text { i. Cables and hardware } \\
\text { ii. Junction box } \\
\text { iii. Lightning arrester, earthing kit }\end{array}$ & $48,00,000$ \\
\hline 6 & $\begin{array}{l}\text { Miscellaneous cost } \\
\text { i. SCADA } \\
\text { ii. Testing equipment's } \\
\text { iii. Street lighting system } \\
\text { iv. CCTV camera }\end{array}$ & $39,00,000$ \\
\hline Total & & $15,40,34,000$ \\
\hline
\end{tabular}

$$
\left(S_{S V}\right)_{N P V}=\frac{S V}{(1+d)^{n}}
$$

The payback period essentially measures the time elapsed between the point of initial investment and the point at which the accumulated savings, net of other accumulated costs are sufficient to offset the initial investment outlay. The payback period of a system can be calculated using the following equation [24]

$$
P B P=\frac{\left(C_{\text {out }}\right)_{t}}{S_{A E G}}
$$

The unit cost is associated with the rate at which electricity must be produced by the system over its lifetime. It can be expressed as

$$
\begin{gathered}
C_{u}=\frac{C_{A U}}{E_{\text {generated }}} \\
C_{A U}=\left(C_{\text {out }}\right)_{t} \times\left\{\frac{d(1+d)^{n}}{(1+d)^{n}-1}\right\}
\end{gathered}
$$

\section{Results and discussion}

In the present study, different output parameters of the 2 MW SPV power plant have been obtained for different locations of the NE states as mentioned in the previous sections. In the present section SPV power plant performance parameters for the NE states are compared with three other locations of India with high solar insolation values, viz., Jaipur, New Delhi and Ahmedabad. The system production and specific production is found to be maximum in the case of Aizawl, which may be due to the higher level of solar irradiation owing to its proximity with the Tropic of Cancer. The system production for Aizawl is $3928 \mathrm{MWh} /$ year, which is only $4 \%$ less than that of Delhi and approximately $1 \%$ less than that of Jaipur. The performance ratio (PR) describes the relationship between the actual and theoretical energy outputs of the PV power plant. $\mathrm{PR}$ is found to be maximum in case of Guwahati and Gangtok with a value of 0.855 due to the favorable climatic conditions that results in the minimum loss. However, PR is found to be $0.814,0.829$ and 0.820 for Jaipur, Ahmedabad and New Delhi, respectively. Performance ratio gives the actual energy that is available to deliver to the grid. Different losses which occur in power plants for eight different locations of NE states are presented in table 15.

The life cycle conversion efficiency is calculated over a life span of 25 years which is summarized in table 16. The maximum and minimum conversion efficiencies of $66.7 \%$ and 59.2\% have been observed for Guwahati and Itanagar, respectively. A higher values of the maximum conversion efficiency for Guwahati may be due to a favourable climatic conditions, such as, longer duration of sunshine and high intensity of solar insolation. Another measure of plant performance is the Capacity Utilization Factor (CUF), which is found to be 20.1 for Aizawl, due to higher insolation value as compared to other locations considered, followed by Guwahati which is $19 \%$. When compared after considering the carbon dioxide mitigation, Aizawl is found to mitigate maximum amount of carbon dioxide followed by Guwahati.

The most important objective of a power producer is to investigate the economic viability of the power plant and also to supply electricity to the consumers at a price which is cheap and affordable. Moreover, primary concern for the investor is to earn profit. This criterion of the investor can be fulfilled through NPV method and by calculating the unit cost of electricity to be generated. The capital city of Mizoram (Aizawl) provides the minimum unit cost of electricity followed by Guwahati and Agartala. A comparison of unit cost of electricity generated by PV plants among all the capital cities of NE states is shown in figure 17. When plants are evaluated considering payback period, PV plant in Guwahati is found to achieve payback in 6.38 years whereas for Itanagar it is 15.51 years. Table 17 provides the unit cost of electricity generated by PV plants in all the NE state capitals along with the prevailing unit cost of electricity [97] and payback period and NPV. It is observed that the plant is not feasible in case of Itanagar due to its negative NPV value. This is mainly because of the low prevailing electricity price due to high generation of electricity in the state using hydro power. Furthermore, negative NPV may be due to a lower solar insolation in the location. 
Table 15. Performance analysis of power plants for different locations of NE India.

\begin{tabular}{|c|c|c|c|c|c|c|c|c|}
\hline Location & Guwahati & Shillong & Agartala & Imphal & Kohima & Aizawl & Itanagar & Gangtok \\
\hline System Production (MWh/year) & 3722 & 3370 & 3622 & 3393 & 3367 & 3928 & 2777 & 3249 \\
\hline Specific Production $\left(\mathrm{kWh} / \mathrm{kW}_{\mathrm{p}} /\right.$ year $)$ & 1668 & 1510 & 1623 & 1520 & 1509 & 1760 & 1244 & 1455 \\
\hline Performance ratio & 0.855 & 0.842 & 0.827 & 0.839 & 0.852 & 0.829 & 0.847 & 0.855 \\
\hline Normalized production $\left(\mathrm{kWh} / \mathrm{kW}_{\mathrm{p}} /\right.$ day $)$ & 4.57 & 4.14 & 4.45 & 4.16 & 4.13 & 4.82 & 3.41 & 3.99 \\
\hline Array Loss $\left(\mathrm{kWh} / \mathrm{kW}_{\mathrm{p}} /\right.$ day $)$ & 0.69 & 0.70 & 0.85 & 0.72 & 0.64 & 0.90 & 0.55 & 0.60 \\
\hline System Loss (kWh/kW $\mathrm{p}_{\mathrm{p}} /$ day) & 0.09 & 0.08 & 0.08 & 0.08 & 0.08 & 0.09 & 0.07 & 0.08 \\
\hline PV loss due to irradiance level (\%) & 1.1 & 1.4 & 1.1 & 1.3 & 1.4 & 1.0 & 1.8 & 1.5 \\
\hline PV loss due to temperature $(\%)$ & 8.7 & 9.7 & 11.5 & 10.0 & 8.5 & 11.4 & 8.5 & 8.1 \\
\hline Module array mismatch loss & 1.0 & 1.0 & 1.0 & 1.0 & 1.0 & 1.0 & 1.0 & 1.0 \\
\hline Ohmic wiring loss $(\%)$ & 1.1 & 1.1 & 1.1 & 1.1 & 1.1 & 1.2 & 0.9 & 1.0 \\
\hline Inverter Loss during operation (\%) & 1.9 & 1.8 & 1.8 & 1.8 & 1.9 & 1.8 & 1.9 & 1.9 \\
\hline
\end{tabular}

Table 16. Complete Life cycle evaluation of NE states capitals of India.

\begin{tabular}{lcccccc}
\hline Location & EPF & EPBT & LCCE & CUF & $\mathrm{Net} \mathrm{CO}_{2}$ mitigation (tonnes of $\mathrm{CO}_{2}$ ) & Carbon Credit (INR) \\
\hline Guwahati & 0.166 & 6.015 & 0.667 & 0.190 & 111648607.6 & 74804567.07 \\
Shillong & 0.151 & 6.643 & 0.636 & 0.172 & 97744607.56 & 65488887.07 \\
Agartala & 0.162 & 6.181 & 0.641 & 0.185 & 107698607.6 & 72158067.07 \\
Imphal & 0.152 & 6.598 & 0.636 & 0.174 & 98653107.56 & 66097582.07 \\
Kohima & 0.150 & 6.649 & 0.644 & 0.172 & 97626107.56 & 65409492.07 \\
Aizawl & 0.175 & 5.699 & 6.658 & 0.201 & 719785607.6 & 80256357.07 \\
Itanagar & 0.124 & 8.061 & 0.592 & 0.142 & 74321107.56 & 49795142.07 \\
Gangtok & 0.145 & 6.890 & 0.638 & 0.166 & 92965107.56 & 62286622.07 \\
\hline
\end{tabular}

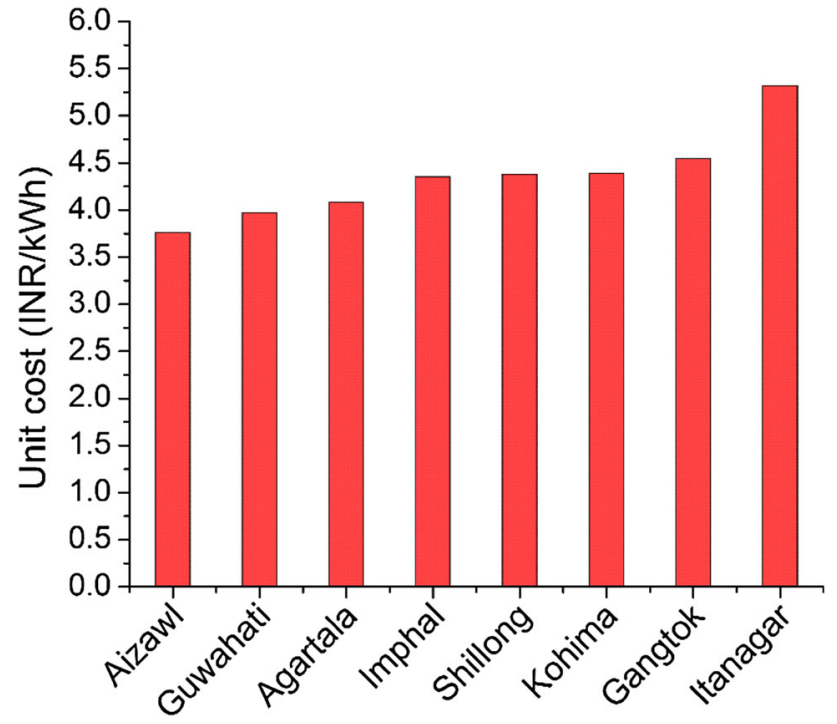

Figure 17. Unit cost of electricity generated by PV power plant in different locations of NE India.

\section{Conclusions}

The present study systematically analyzes the climatic data of NE region of India collected from various sources and based on the analysis an attempt has been made to present the viability of SPV power plants in NE India. The design of the SPV plant was explained thoroughly with the help of theoretical method taking care of different losses and influencing parameters. This theoretical calculation was followed by simulation of $2 \mathrm{MW}$ power plants in different NE state capitals. From this study, it is confirmed that seven out of eight state capitals of NE India are suitable for solar PV power plant installation both technically and economically. The state capital of Arunachal Pradesh (Itanagar) does not qualify the NPV test. The study considered the location of Itanagar as a representative location for Arunachal Pradesh and there may be other locations where installation of MW level power plant is feasible. The study draws the following important conclusions:

Table 17. Summary of financial assessment of NE states.

\begin{tabular}{|c|c|c|c|c|c|c|c|c|}
\hline Location & Guwahati & Shillong & Agartala & Imphal & Kohima & Aizawl & Itanagar & Gangtok \\
\hline$T_{e}(\mathrm{INR} / \mathrm{kWh})$ & 7.25 & 5.7 & 7.2 & 6 & 7 & 5.1 & 4 & 5 \\
\hline$C_{u}(\mathrm{INR} / \mathrm{kWh})$ & 3.97 & 4.39 & 4.08 & 4.36 & 4.39 & 3.76 & 5.32 & 4.55 \\
\hline$N P V$ (in lakhs of INR) & 1470.97 & 550.74 & 1363.73 & 686.72 & 1066.75 & 648.24 & -408.0 & 199.95 \\
\hline$P B P($ years) & 6.38 & 8.97 & 6.61 & 8.46 & 7.31 & 8.60 & 15.51 & 10.60 \\
\hline
\end{tabular}


- The capital city of Assam (Guwahati) was found to have the maximum conversion efficiency of $66.7 \%$ and the lowest conversion efficiency was found to be $59.2 \%$ for the capital city of Arunachal Pradesh (Itanagar).

- The maximum system yield and specific production were found to be $3928 \mathrm{MWh} / \mathrm{year}$ and $1760 \mathrm{kWh} /$ $\mathrm{kWp} /$ year, respectively, for the state capital of Mizoram (Aizawl) which is comparable with that of Delhi and Jaipur.

- In case of carbon dioxide mitigation, state capital of Mizoram (Aizawl) is found to mitigate the maximum volume of carbon dioxide followed by the state capital of Assam (Guwahati).

- The state capital of Mizoram (Aizawl) gives the minimum unit cost of electricity generated, 4.08 INR/ unit.

- PV plant in the state capital of Assam (Guwahati) is found to achieve payback quite fast in just 6.38 years whereas the longest period was recorded for Itanagar (15.51 years).

- The state capital of Mizoram (Aizawl) and Assam (Guwahati) are the most suitable locations for installation of SPV plant amongst the NE capitals.

\section{Acknowledgements}

This work is a part of Start-up project (Grant Number: CEE/SG/IITG/PK1134/001) awarded to Dr. Pankaj Kalita, Assistant Professor, Centre for Energy, Indian Institute of Technology, Guwahati, Assam, India. The financial support extended by Indian Institute of Technology Guwahati is gratefully acknowledged.

\section{List of symbols}

$\begin{array}{ll}A_{A \text { Acable }} & \text { Cross-sectional area of AC cable }\left(\mathrm{mm}^{2}\right) \\ A_{D C \text { Cable }} & \text { Cross-sectional area of DC cable }\left(\mathrm{mm}^{2}\right) \\ C_{A U} & \text { Annualized uniform cost (INR) } \\ \left(\mathrm{CO}_{2}\right)_{e} & \begin{array}{l}\mathrm{CO}_{2} \text { emission from the embodied energy } \\ \left.\text { (tonnes of } \mathrm{CO}_{2}\right)\end{array} \\ C_{\text {cap }} & \text { The capital cost of PV plant (INR) } \\ C_{e} & \text { Cost for electrical connection (INR) } \\ C_{e \& c} & \text { Erection and commissioning cost (INR) } \\ \left(\mathrm{CO}_{2}\right)_{m} & \begin{array}{l}\mathrm{CO}_{2} \text { mitigation for the PV power plant } \\ \text { (tonnes of } \mathrm{CO}_{2} / \text { year) }\end{array} \\ \left(\mathrm{CO}_{2}\right)_{n e t} & \begin{array}{l}\text { Net } \mathrm{CO}_{2} \text { mitigation for the PV power plant } \\ \left.\text { (tonnes of } \mathrm{CO}_{2}\right)\end{array} \\ \cos \varphi & \text { The power factor } \\ C_{m} & \text { Module cost (INR) } \\ C_{m i s} & \text { Miscellaneous cost (INR) } \\ C_{m s} & \text { Cost of mounting and structures (INR) } \\ \left(C_{\text {in }}\right)_{t} & \text { Total inflow of money (INR) } \\ C_{\text {inv }} & \text { Inverter cost, Indian Rupee (INR) } \\ C_{l} & \text { Land cost (INR) } \\ \left(C_{\text {out }}\right)_{t} & \text { Total outflow of money (INR) }\end{array}$

$\left(C_{o \& m}\right)_{a}$

$\left(C_{o \& m}\right)_{N P V}$

D

$d$

$E_{\text {embodied }}$

$E_{\text {generated }}$

$E_{\text {installation }}$

$E_{\text {material }}$

$E_{\text {manufacturing }}$

$E_{o \& p}$

$E_{\text {peak }}$

$E_{\text {solar }}$

$E_{\text {transport }}$

G

$g$

h

$I_{A C}$

$I_{D C}$

$I_{I n v-D C}$

$I_{S C-E f f}$

$I_{S C-S T C}$

$L$

$L_{\text {Accable }}$

$L_{\text {DCcable }}$

$L_{\text {plant }}$

$L_{S H}$

$N_{I n v}$

$P_{T C}$

$P_{S T C}$

$T_{a m b}$

SV

$T_{o p}$

$T_{e}$

$T_{S T C}$

$V_{A C}$

$V_{M a x-E f f}$

$V_{M i n-E f f}$

$V_{M P}$

$V_{M P-S T C}$

$V_{O C-S T C}$

$\left(S_{A E G}\right)_{N P V}$
The annual operation and maintenance cost (INR)

The net present value of operation and maintenance of the plant

Distance between the two rows (m)

Discount rate $(\%)$

Total Embodied energy of the plant $(\mathrm{kWh} /$ $\mathrm{m}^{2}$ )

Annual electricity generated by the plant $\left(\mathrm{kWh} / \mathrm{m}^{2}\right)$

Total energy associated with installation of the PV system $\left(\mathrm{kWh} / \mathrm{m}^{2}\right)$

Total material production energy for PV system $\left(\mathrm{kWh} / \mathrm{m}^{2}\right)$

Total manufacturing energy for PV system $\left(\mathrm{kWh} / \mathrm{m}^{2}\right)$

Total operation and maintenance energy of $\mathrm{PV}$ module over the lifetime $\left(\mathrm{kWh} / \mathrm{m}^{2}\right)$

Peak capacity of the plant $\left(\mathrm{kW}_{\mathrm{p}}\right)$

Annual electricity generated by the plant (MWh/year)

Total energy used for transportation of materials $\left(\mathrm{kWh} / \mathrm{m}^{2}\right)$

Incident solar radiation $\left(\mathrm{W} / \mathrm{m}^{2}\right)$

Inflation rate $(\%)$

Height of the solar module (m)

The current flowing in the cable (A)

The current flowing in the cable (A)

Maximum DC current of inverter (A)

Effective short-circuit current (A)

Short-circuit current at STC (A)

Length of the solar module (m)

The route length of AC cable (m)

The route length of DC cable $(\mathrm{m})$

Life time of the system (years)

Shadow length $(\mathrm{m})$

Number of inverters

Temperature corrected power output (W)

Power output at STC (W)

Ambient temperature of the location $\left({ }^{\circ} \mathrm{C}\right)$

The salvage value (INR)

Operating temperature of the module $\left({ }^{\circ} \mathrm{C}\right)$

Electricity tariff (INR/kWh)

Standard test temperature $\left({ }^{\circ} \mathrm{C}\right)$

The voltage of the grid $(\mathrm{V})$

Maximum effective voltage of the module (V)

Minimum effective voltage of the module (V)

The maximum power point voltage of the string/array (V)

Maximum power voltage at STC (V)

Open circuit Voltage at STC (V)

The present value annual savings from generated electricity of the plant (INR) 


\section{$\left(S_{S V}\right)_{N P V}$}

The present value of saving from salvage value (INR)

$\alpha$

$\varphi$

$\psi$

$\delta$

$\omega$

$\theta$

$\rho$

$\gamma_{I_{s c}}$

$\gamma_{p}$

$\gamma_{V_{o c}}$
Sun elevation angle

Latitude angle for solar PV site

Sun azimuth angle

Solar declination angle

Hour angle

Solar module tilt angle

Resistivity of the wire $\left(\Omega / \mathrm{mm} / \mathrm{mm}^{2}\right)$

Short-circuit temperature coefficient $\left(\% /{ }^{\circ} \mathrm{C}\right)$

Maximum power temperature coefficient $\left(\% /{ }^{\circ} \mathrm{C}\right)$

Open circuit voltage temperature coefficient $\left(\% /{ }^{\circ} \mathrm{C}\right)$

\section{References}

[1] Yergin D 1991 The Prize: The Epic Quest for Oil, Money, and Power. Simon \& Schuster, New York: Free Press

[2] Das D, Kalita P and Roy O 2018 Flat plate hybrid photovoltaic- thermal (PV/T) system: A review on design and development. Renew. Sustain. Energy Rev. 84: 111-130

[3] Goldthau A 2011 Governing global energy: Existing approaches and discourses. Curr. Opin. Environ. Sustain. 3: 213-217

[4] International Energy Agency 2014 Energy Security" EA Energy Technology Systems Analysis Programme Paris. Available: http://www.iea.org/topics/energysecurity/ (accessed October 25, 2017)

[5] Power sector at a glance all India 2016. Available: http:// powermin.nic.in/content/power-sector-glance-all-india (accessed October 6, 2016)

[6] Johannes F, Ge M and Pickens A 2017 World's Top 10 Emitters, and How They've Changed. World Resour. Inst. Available: http://www.wri.org/blog/2017/04/interactivechart-explains-worlds-top-10-emitters-and-how-theyve-chan ged (accessed April 11, 2017)

[7] BP 2017 Energy Outlook. Available: https://safety4sea.com/ wp-content/uploads/2017/01/BP-Energy-Outlook-2017_01.pdf

[8] Al-Maamary H M S, Kazem H A and Chaichan M T 2017 The impact of oil price fluctuations on common renewable energies in GCC countries. Renew. Sustain. Energy Rev. 75: 989-1007

[9] Jain S, Jain N K and Vaughn W J 2018 Challenges in meeting all of India's electricity from solar: An energetic approach. Renew. Sustain. Energy Rev. 82: 1006-1013

[10] Sharma A, Srivastava K and Kar S K 2015 Jawaharlal Nehru national solar mission in India. Energy Sustainability Through Green Energy. Green Energy Technol. In: Sharma A and Kar S (Eds.). New Delhi: Springer 47-67

[11] Bridge to India. SOLAR Including the 2017. Available: https://bridgetoindia.com/report/india-solar-map-september2017/

[12] Ministry of New and Renewable Energy 2016 A new dawn in Renewable Energy- India attains 4th position in global wind power installed capacity. Available: http://pib.nic.in/ newsite/PrintRelease.aspx?relid=155612 (accessed January 29, 2017)

[13] Shukla A K, Sudhakar K, Baredar P and Mamat R 2018 Solar PV and BIPV system: Barrier, challenges and policy recommendation in India. Renew. Sustain. Energy Rev. 82: 3314-3322

[14] Central Statistics Office Energy Statistics 2017. Govt. India 2017. Available: http://mospi.gov.in/sites/default/files/pub lication_reports/Energy_Statistics_2017r.pdf.pdf

[15] MNRE 2017 Annual Report 2016-2017:2. Available: https:// mnre.gov.in/file-manager/annual-report/2016-2017/EN/pdf/ 2.pdf

[16] Indian Chamber of Commerce 2017 Powering the North-East Availability, Accessibility \& Affordability. In: Conference on Energizing North East, Shillong, Meghalaya

[17] Dikshit K R and Dikshit J K 2014 North-East India: Land, People and Economy. Dordrecht: Springer

[18] Li J, Liu F, Li Z, Shao C and Liu X 2018 Grid-side flexibility of power systems in integrating large-scale renewable generations: A critical review on concepts, formulations and solution approaches. Renew. Sustain. Energy Rev. 93: 272-284

[19] Jenniches S 2018 Assessing the regional economic impacts of renewable energy sources- A literature review. Renew. Sustain. Energy Rev. 93: 35-51

[20] Akella A K, Saini R P and Sharma M P 2009 Social, economical and environmental impacts of renewable energy systems. Renew. Energy 34: 390-396.

[21] Muneer T, Asif M and Munawwar S 2005 Sustainable production of solar electricity with particular reference to the Indian economy. Renew. Sustain. Energy Rev. 9: 444-473

[22] Eltawil M A and Zhao Z 2010 Grid-connected photovoltaic power systems: Technical and potential problems-A review. Renew. Sustain. Energy Rev. 14: 112-129

[23] Mitavachan H, Gokhale A and Srinivasan J 2011 A case study of 3-MW scale grid-connected solar photovoltaic power plant at Kolar, Karnataka. Report IISc-DCCC 11 RE 1 August 2011. Divecha Centre For Climate Change Indian Institute Of Science Bangalore 1-38

[24] Kornelakis A and Koutroulis E 2009 Methodology for the design optimisation and the economic analysis of grid-connected photovoltaic systems. IET Renew. Power Gener. 3: 476-492

[25] Chandel M, Agrawal G D, Mathur S and Mathur A 2014 Techno-economic analysis of solar photovoltaic power plant for garment zone of Jaipur city. Case Stud. Therm. Eng. 2: $1-7$.

[26] Sukumaran S and Sudhakar K 2017 Fully solar powered Raja Bhoj International Airport: A feasibility study. Resour. Technol. 3: 309-316

[27] Mondal M A H and Islam A K M S 2011 Potential and viability of grid-connected solar PV system in Bangladesh. Renew. Energy 36: 1869-1874

[28] Sukumaran S and Sudhakar K 2017 Fully solar powered airport: A case study of Cochin International airport. J. Air Transp. Manag. 62: 176-188

[29] Moharil R M and Kulkarni P S 2007 A case study of solar photovoltaic power system at Sagardeep Island, India. Renew. Sustain. Energy Rev. 13: 673-681

[30] Ayompe L M, Duffy A, McCormack S J and Conlon M 2011 Measured performance of a $1.72 \mathrm{~kW}$ rooftop grid connected photovoltaic system in Ireland. Energy Convers. Manag. 52: $816-825$ 
[31] Velasco G, Guinjoan F, Pique R, Roman M and Conesa A 2011 Simulation-based criteria for the power sizing of grid-connected PV systems. Int. Rev. Model Simulations 4: 2524-2533

[32] Ramoliya J V 2015 Performance Evaluation of Grid-connected Solar Photovoltaic plant using PVSYST Software. $J$. Emerg. Technol. Innov. Res. 2: 372-378. Available :http:// www.jetir.org/papers/JETIR1502036.pdf

[33] Ramli M A M, Hiendro A, Sedraoui K and Twaha S 2015 Optimal sizing of grid-connected photovoltaic energy system in Saudi Arabia. Renew. Energy 75: 489-495

[34] Mondol J D, Yohanis Y G and Norton B 2006 Optimal sizing of array and inverter for grid-connected photovoltaic systems. Sol. Energy 80: 1517-1539

[35] Pearsall N 2016 Introduction to photovoltaic system performance. In: The Perform. of Photovolt. Syst. Model. Meas. Assess. Pearsall N, editor. Duxford: Woodhead publishing. $1-19$

[36] Woyte A and Goy S 2016 Large grid-connected photovoltaic power plants: Best practices for the design and operation of large photovoltaic power plants. In: The Perform. Photovolt. Syst. Model. Meas. Assess. Pearsall N, editor. Duxford: Woodhead publishing. 321-333

[37] Hasapis D, Savvakis N, Tsoutsos T, Kalaitzakis K, Psychis S and Nikolaidis N P 2017 Design of large scale prosuming in Universities: The solar energy vision of the TUC campus. Energy Build. 141: 39-55

[38] Rawat R, Kaushik S C and Lamba R 2016 A review on modeling, design methodology and size optimization of photovoltaic based water pumping, standalone and grid connected system. Renew. Sustain. Energy Rev. 57: 1506-1519

[39] Anzalchi A and Sarwat A 2017 Overview of technical specifications for grid-connected photovoltaic systems. Energy Convers. Manag. 152: 312-327

[40] Berwal A K, Kumar S, Kumari N, Kumar V and Haleem A 2017 Design and analysis of rooftop grid tied $50 \mathrm{~kW}$ capacity Solar Photovoltaic (SPV) power plant. Renew. Sustain. Energy Rev. 77: 1288-1299

[41] Wu Y-K, Lin J-H and Lin H-J 2017 Standards and Guidelines for Grid-Connected Photovoltaic Generation Systems: A Review and Comparison. IEEE Trans. Ind. Appl. 53: 3205-3216

[42] Al Garni and H Z Awasthi A 2018 Solar PV Power Plants Site Selection: A Review. Adv. Renew. Energies Power Technol. Vol 1: Solar and Wind Energies. In: Yahyaoui I (editor), Elsevier. 57-75

[43] Sidi C E B E, Ndiaye M L, El Bah M, Mbodji A, Ndiaye A and Ndiaye P A 2016 Performance analysis of the first largescale (15 MWp) grid-connected photovoltaic plant in Mauritania. Energy Convers. Manag. 119: 411-421

[44] Senol M, Abbasoglu S, Kukrer O and Babatunde A A 2016 A guide in installing large-scale PV power plant for self consumption mechanism. Sol. Energy 132: 518-537

[45] Babatunde A A, Abbasoglu S and Senol M 2018 Analysis of the impact of dust, tilt angle and orientation on performance of PV Plants. Renew. Sustain. Energy Rev. 90: 1017-1026

[46] Halliday A and Kashyap S G 2016 Massive push to railway infrastructure under way in Northeast. The Indian Express. Available: https://indianexpress.com/article/explained/thenew-northeast-expresses/
[47] Parretta A, Sarno A and Vicari L R M 1998 Effects of solar irradiation conditions on the outdoor performance of photovoltaic modules. Opt. Commun. 153: 153-163

[48] Das D, Kalita P, Dewan A and Tanweer S 2019 Development of a novel thermal model for a PV/T collector and its experimental analysis. Sol. Energy.188: 631-643

[49] Xydis G 2013 The wind chill temperature effect on a largescale PV plant- an exergy approach. Prog. Photovoltaics 21: 1611-1624

[50] Sayyah A, Horenstein M N and Mazumder M K 2014 Energy yield loss caused by dust deposition on photovoltaic panels. Sol. Energy 107: 576-604

[51] Ndiaye A, Kebe C M F, Ndiaye P A, Charki A, Kobi A and Sambou V 2013 Impact of dust on the photovoltaic (PV) modules characteristics after an exposition year in Sahelian environment: The case of Senegal. Int. J. Phys. Sci. 8: 1166-1173

[52] Ndiaye A, Charki A, Kobi A, Kebe C M F, Ndiaye P A and Sambou V 2013 Degradations of silicon photovoltaic modules: A literature review. Sol. Energy 96: 140-151

[53] Al-Sabounchi A M, Yalyali S A and Al-Thani H A 2013 Design and performance evaluation of a photovoltaic gridconnected system in hot weather conditions. Renew. Energy 53: 71-78

[54] Jain S K, Kumar V and Saharia M 2013 Analysis of rainfall and temperature trends in northeast India. Int. J. Climatol. 33: 968-978

[55] Bhattacharya T, Chakraborty A K and Pal K 2014 Effects of Ambient Temperature and Wind Speed on Performance of Monocrystalline Solar Photovoltaic Module in Tripura, India. J. Sol. Energy 2014: 1-5

[56] Dubey S, Sarvaiya J N and Seshadri B 2013 Temperature dependent photovoltaic (PV) efficiency and its effect on PV production in the world- A review. Energy Procedia 33: 311-321

[57] Mekhilef S, Safari A, Mustaffa W E S, Saidur R, Omar R and Younis M A A 2012 Solar energy in Malaysia: Current state and prospects. Renew. Sustain. Energy Rev. 16: 386-396

[58] Kaldellis J K, Kapsali M and Kavadias K A 2014 Temperature and wind speed impact on the efficiency of PV installations. Experience obtained from outdoor measurements in Greece. Renew Energy 66: 612-624

[59] Prokop P and Walanus A 2015 Variation in the orographic extreme rain events over the Meghalaya Hills in northeast India in the two halves of the twentieth century. Theor. Appl. Climatol. 121: 389-399

[60] Suri M, Huld T A, Dunlop E D and Ossenbrink H A 2007 Potential of solar electricity generation in the European Union member states and candidate countries. Sol Energy 81: 1295-1305

[61] World Weather Online 2017. Available: https://www.world weatheronline.com/ (accessed September 26, 2017)

[62] Kazem H A and Chaichan M T 2015 Effect of humidity on photovoltaic performance based on experimental study. Int. J. Appl. Eng. Res. 10: 43572-43577

[63] Touati F A, Al-Hitmi M A and Bouchech H J 2013 Study of the effects of dust, relative humidity, and temperature on solar PV performance in Doha: Comparison between monocrystalline and amorphous PVS. Int. J. Green Energy 10: $680-689$ 
[64] Mani M and Pillai R 2010 Impact of dust on solar photovoltaic (PV) performance: Research status, challenges and recommendations. Renew. Sustain. Energy Rev. 14: 3124-3131.

[65] Khatib T, Mohamed A and Sopian K 2013 A review of photovoltaic systems size optimization techniques. Renew. Sustain. Energy Rev. 22: 454-465

[66] GSES 2013 Grid-Connected PV Systems: Design and Installation. $1^{\text {st }}$ Ed GSES India Sustainable Energy. Available: http:/gses.in/publications/books/grid-connected-pv-sys tems-design-and-installation.

[67] Labouret A and Villoz M 2010 Solar Photovoltaic Energy. Stevenage UK: The Institution of Engineering and Technology (IET)

[68] TATA Solar Power: Technical Datasheet TP300 series. Available: https://www.enf.com.cn/Product/pdf/Crystalline/ 5b233d229e43d.pdf

[69] Bonfiglioli: Three-phase grid- connected photovoltaic inverter: RPS 450. Available: http://opis.cz/vectron/pdf/RPS/ Cat_RPS450_gb.pdf

[70] Radziemska E 2003 The effect of temperature on the power drop in crystalline silicon solar cells. Renew Energy 28: 1-12

[71] Chakraborty S and Sadhu P K 2015 Technical mapping of solar photovoltaic for the Coal City of India. Renewables Wind Water, Sol. 2: 11.

[72] Sukhatme S P and Nayak J K 2017 Solar Energy. 4 ${ }^{\text {th }}$ Ed McGraw Hill Education

[73] Ayadi O, Al-Assad R and Al Asfar J 2018 Techno-economic assessment of a grid connected photovoltaic system for the University of Jordan. Sustain. Cities Soc. 39: 93-98

[74] Kumar B S and Sudhakar K 2015 Performance evaluation of $10 \mathrm{MW}$ grid connected solar photovoltaic power plant in India. Energy Reports 1: 184-192

[75] Rashwan S S, Shaaban A M and Al-Suliman F 2017 A comparative study of a small-scale solar PV power plant in Saudi Arabia. Renew. Sustain. Energy Rev. 80: 313-318

[76] Rehman S, Ahmed M A, Mohamed M H and Al-Sulaiman F A 2017 Feasibility study of the grid connected 10MW installed capacity PV power plants in Saudi Arabia. Renew. Sustain. Energy Rev. 80: 319-329

[77] Kumar N M, Kumar M R, Rejoice P R and Mathew M 2017 Performance analysis of $100 \mathrm{kWp}$ grid connected Si-poly photovoltaic system using PVsyst simulation tool. Energy Procedia 117: 180-189

[78] Barua S, Prasath R A and Boruah D 2017 Rooftop Solar Photovoltaic System Design and Assessment for the Academic Campus Using PVsyst Software. Int. J. Electron. Electr. Eng. 5: 76-83

[79] Karki P, Adhikary B and Sherpa K 2012 Comparative study of grid-tied photovoltaic (PV) system in Kathmandu and Berlin using PVsyst. In: Proc. IEEE Third Int. Conf. Sustain. Energy Technol. Kathmandu, Nepal: IEEE. 196-199

[80] Sharma V and Chandel S S 2013 Performance analysis of a $190 \mathrm{kWp}$ grid interactive solar photovoltaic power plant in India. Energy 55: 476-485
[81] Okello D van, Dyk E E and Vorster F J 2015 Analysis of measured and simulated performance data of a $3.2 \mathrm{kWp}$ gridconnected PV system in Port Elizabeth, South Africa. Energy Convers. Manag. 100: 10-15.

[82] Charles R 2015 Optimum Tilt of Solar Panels. Available: http://www.solarpaneltilt.com/ (accessed November 12, 2016)

[83] Indian Meteorological Department 2010, Annual Report 2010. Available: http://metnet.imd.gov.in/imdnews/ar2010.pdf

[84] Castellano N N, Gazquez Parra J A, Valls-Guirado J and Manzano-Agugliaro F 2015 Optimal displacement of photovoltaic array's rows using a novel shading model. Appl. Energy 144: 1-9

[85] Deline C, Dobos A, Janzou S, Meydbray J and Donovan M 2013 A simplified model of uniform shading in large photovoltaic arrays. Sol. Energy 96: 274-282

[86] Bouzguenda M, Al Omair A, Al Naeem A, Al-Muthaffar M and Wazir O B 2014 Design of an off-grid $2 \mathrm{~kW}$ solar PV system. In: Proc. 9th Int Conf Ecol Veh Renew Energies, EVER 2014. Monte-Carlo, Monaco: IEEE 1-6

[87] Ren Z, Jacques S, Bissey S, Batut N, Schellmanns A and Caldeira A 2014 PVLab: an innovative and flexible simulation tool to better size photovoltaic units. In: Proc. International Conference on Renewable Energies and Power Quality, ICREPQ 2014. Cordoba, Spain: Renew. Energies Power Qual. J. 1: 87-91

[88] Draft Environmental impact report, Environmental impact analysis, 2017, ESA PCR, Alamada. Available: https://planning. lacity.org/eir/668SoAlamedaStreet/Deir/4.1\%20Aesthetics.pdf

[89] Climate-Data.org. 2017 Climate Data for Cities Worldwide. Available: https://en.climate-data.org/ (accessed October 25, 2017)

[90] Chakraborty S, Sadhu P K and Pal N 2015 Technical mapping of solar PV for ISM-an approach toward green campus. Energy Sci. Eng. 3: 196-206

[91] Sherwani A F, Usmani J A and Varun 2010 Life cycle assessment of solar PV based electricity generation systems: A review. Renew. Sustain. Energy Rev. 14: 540-544

[92] Tiwari A, Barnwal P, Sandhu G S and Sodha M S 2009 Energy metrics analysis of hybrid- photovoltaic (PV) modules. Appl. Energy 86: 2615-2625

[93] Khatri R 2016 Design and assessment of solar PV plant for girls hostel (GARGI) of MNIT University, Jaipur city: A case study. Energy Reports 2: 89-98

[94] Kandpal T and Garg H 2003 Financial evaluation of renewable energy technologies. Delhi: Macmillan India Ltd.

[95] Renewable energy discount rate survey results - 2018. Available: https://www.grantthornton.co.uk/globalassets/1.member-firms/united-kingdom/pdf/documents/renewableenergy-discount-rate-survey-results-2018.pdf

[96] India Inflation Rate. Available: https://tradingeconomics. com/india/inflation-cpi

[97] Domestic Electricity LT Tariff Slabs and Rates for all states in India in 2019. Available: https://www.bijlibachao.com/ news/domestic-electricity-lt-tariff-slabs-and-rates-for-allstates-in-india-in.html (accessed June 28, 2019) 